\title{
EDUARDO KANASHIRO
}

Consumo desagregado de energia: técnicas de monitoramento não intrusivo

São Paulo

2016 


\section{EDUARDO KANASHIRO}

Consumo desagregado de energia: técnicas de monitoramento não intrusivo

Dissertação apresentada à Escola

Politécnica da Universidade de São Paulo

para obtenção do título de Mestre em

Ciências

Área de Concentração:

Sistemas de Potência

Orientador:

Prof. Dr. Marco Antonio Saidel

São Paulo

2016 
Este exemplar foi revisado e corrigido em relação à versão original, sob responsabilidade única do autor e com a anuência de seu orientador.

São Paulo, de de

Assinatura do autor:

Assinatura do orientador:

Catalogação-na-publicação

Kanashiro, Eduardo

Consumo desagregado de energia: técnicas de monitoramento não intrusivo. / E. Kanashiro -- versão corr. -- São Paulo, 2015.

$61 \mathrm{p}$.

Dissertação (Mestrado) - Escola Politécnica da Universidade de São Paulo. Departamento de Engenharia de Energia e Automação Elétricas.

1.Energia (Administração) 2.Consumo de energia elétrica I.Universidade de São Paulo. Escola Politécnica. Departamento de Engenharia de Energia e Automação Elétricas II.t. 


\section{AGREDECIMENTOS}

Ao Prof. Dr. Marco Antonio Saidel, pela orientação, amizade e pelas valorosas contribuições para o desenvolvimento deste trabalho.

Ao Prof. Dr. Alberto Hernandez Neto e ao Prof. Dr. André Luiz Veiga Gimenes pelas também valorosas contribuições na banca de qualificação.

À FDTE e ao Departamento de Engenharia de Energia e Automação Elétricas pela bolsa concedida.

E aos familiares, amigos e demais pessoas que de alguma forma contribuíram para que este trabalho fosse desenvolvido. 


\section{RESUMO}

As Ações de Eficiência Energética encontram grandes barreiras para sua implantação. Um dos motivos pode estar na falta de conhecimento do tomador de decisão que, para evitar o custo inicial mais elevado de um equipamento eficiente, opta por instalar um equipamento mais barato, mas que consequentemente consome mais energia e aumenta os dispêndios com a eletricidade. Os sistemas de gestão de energia visam demonstrar a origem das despesas relacionadas ao consumo de energia elétrica, conscientizando os usuários acerca de tais custos. Muitos usuários não enxergam a possibilidade de economia de energia e de dinheiro, ao investir em equipamentos mais eficientes. Muitos consideram as faturas de energia como despesas fixas, logo, sem exigência de acompanhamento. Fato não compatível com os dias atuais. Ao identificar o consumo desagregado de energia da instalação, os usuários poderão avaliar os impactos de suas atividades em relação ao consumo de energia, assim com seu custo nas faturas de energia. A medição direta dos equipamentos reproduz o valor mais preciso do consumo desagregado. Entretanto, para muitas instalações esta prática é inviável, pois seus circuitos são compartilhados por diversos tipos de equipamentos e os custos de aquisição, implantação e leitura dos medidores podem se tornar proibitivos. É possível obter o valor do consumo desagregado por inspeção da instalação, que consiste no levantamento das características elétricas dos equipamentos, suas respectivas potências e períodos de utilização. Esse método, no entanto não é tão preciso na análise do consumo desagregado, pois envolve uma série de estimativas acerca da utilização dos equipamentos, que nem sempre são acertadas. Visando contornar estas situações, as técnicas de monitoramento não intrusivo de carga passaram a buscar na curva de carga as assinaturas elétricas dos equipamentos, para identificar seus períodos de funcionamento e assim obter o consumo desagregado.

Palavras-chave: Análise de Curva de Carga. Consumo Desagregado. Eficiência Energética. Monitoramento Não Intrusivo de Carga. Sistema de Gestão de Energia. 


\begin{abstract}
The energy efficiency programs face huge difficulties to be deployed. The reason may be the lack of knowledge about total costs in acquires less efficient devices, which is cheaper, though the increases in energy bills eliminate this initial economy. Thereby, the Energy Management Systems aims to demonstrate the relation between the user's behavior and the electric power consumption. Many managers consider the electric bill as a fixed cost, without require tracking its origin. This means waste of energy and money. Analyzing the facility by sectors may improve the understanding about the costs in electricity and the knowledge about the disaggregated energy consumption, though is not always an easy issue to be obtained. Monitoring each equipment provides the exactly amount of energy is used in that system. However the costs of acquirement, implementation and monitoring these meters may become prohibitively. This way, the researches about nonintrusive load monitoring aim to demonstrate where the energy is being used and how it can be minimized.
\end{abstract}

Keywords: Disaggregated Consumption. Energy Efficiency. Energy Management System. Load Shape Analysis. Nonintrusive Load Monitoring. 


\section{LISTA DE FIGURAS}

Figura 1 - Estrutura do Sistema de Gestão de Energia ........................................ 14

Figura 2 - Exemplo de um processo de determinação da economia..................... 18

Figura 3 - A influência do diâmetro da lâmpada no rendimento da luminária........ 25

Figura 4 - Efeitos no consumo com a variação da temperatura externa. ............... 32

Figura 5 - Curva de carga de cinco geladeiras de modelos e potências distintos. 35

Figura 6 - Metodologia "Janela com Margens"............................................... 40

Figura 7 - Exemplo da metodologia "Amostra Deslocada" .................................. 41

Figura 8 - Região de agrupamento dos eventos............................................ 44

Figura 9 - Curva de carga residencial ........................................................ 50

Figura 10 - Identificação dos eventos no dia 18 de abril de 2011 ......................50

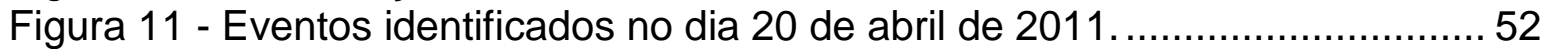

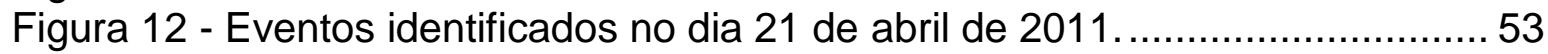

Figura 13 - Período inicial da curva de carga do dia 20/04/2011 ....................... 54

Figura 14 - Eventos identificados na curva de carga no período da madrugada... 55

Figura 15 - Curva de carga do dia 20 de abril de 2011 ....................................5 55

Figura 16 - Eventos identificados no período noturno. .....................................56

Figura 17 - Curva de carga do refrigerador medida na tomada de alimentação do

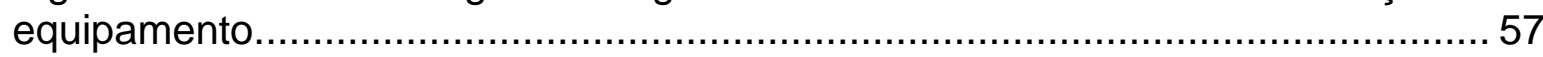

Figura 18 - Curva de carga do refrigerador obtida através do algoritmo proposto. 57

Figura 19 - Curva de Carga do IIITD em uma terça-feira ....................................5 59

Figura 20 - Curva de carga do IIITD em um domingo .........................................6 60

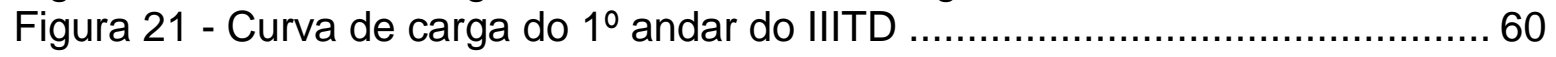




\section{LISTA DE ABREVIATURAS E SIGLAS}

AEE Ação de Eficiência Energética

AVAC Aquecimento, Ventilação e Ar Condicionado

BERDS BERkeley EneRgy Disaggregation Dataset

BLUED Building-Level fUlly labeld Electricity Disaggregation

COMBED Commercial Building Energy Dataset

Conpet Programa Nacional da Racionalização do Uso dos Derivados do

Petróleo e do Gás Natural

CUASO Cidade Universitária "Armando de Salles Oliveira"

EE-EPUSP Engenharia Elétrica da Escola Politécnica da USP

Eletrobras Centrais Elétricas Brasileiras S.A.

ENCE Etiqueta Nacional de Conservação de Energia

ESCO Energy Services Company

GEE Gases de Efeito Estufa

IAG/USP Instituto de Astronomia, Geofísica e Ciências Atmosféricas da USP

IIITD Indraprastha Institute of Information Technology - Delhi

Inmetro Instituto Nacional de Metrologia, Qualidade e Segurança

ISO International Organization for Standardization

LED Light Emitting Diode

M\&V Medição e Verificação

NILM Non Intrusive Load Monitoring

PBE Programa Brasileiro de Etiquetagem

Petrobras Petróleo Brasileiro S.A.

PDCA Plan-Do-Check-Act 
PIMVP Protocolo Internacional de Medição e Verificação de Performance

Procel Programa Nacional de Conservação de Energia Elétrica

Pureusp Programa Permanente para Uso Racional e Eficiente de Energia na USP

REDD Reference Energy Disaggregation Dataset

RGR Reserva Global de Reversão

ROL Receita Operacional Líquida

SISGEN Sistema de Gerenciamento de Energia da USP

USP $\quad$ Universidade de São Paulo 


\section{SUMÁRIO}

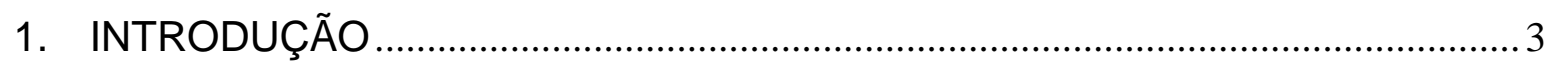

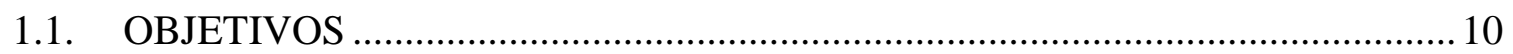

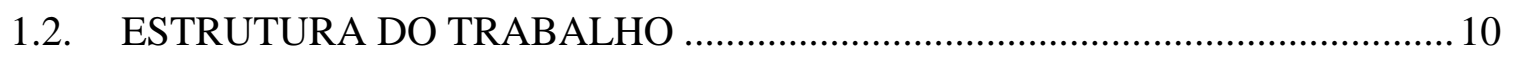

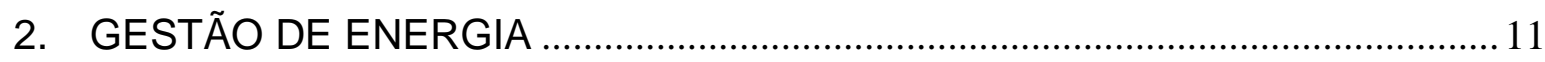

2.1. SISTEMAS DE GESTÃO DE ENERGIA …………...........................................12

2.2. PROTOCOLO INTERNACIONAL DE MEDIÇÃO E VERIFICAÇÃO DE DESEMPENHO ENERGÉTICO .......................................................................... 16

2.2.1. Estrutura do PIMVP ............................................................................. 17

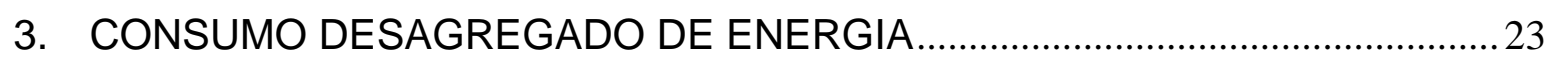

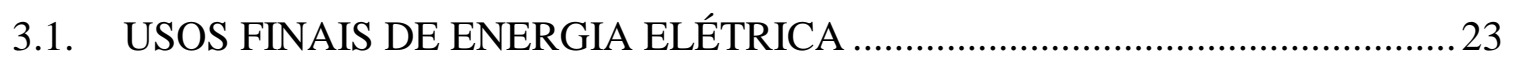

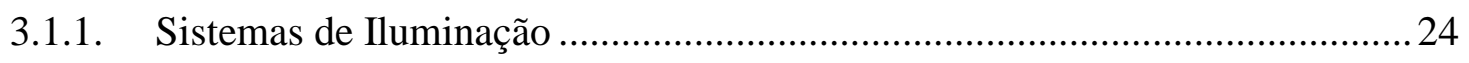

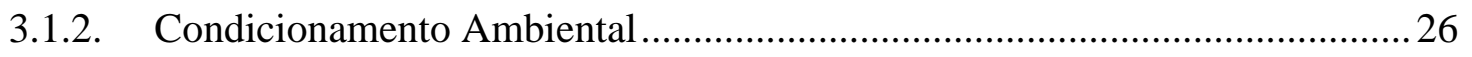

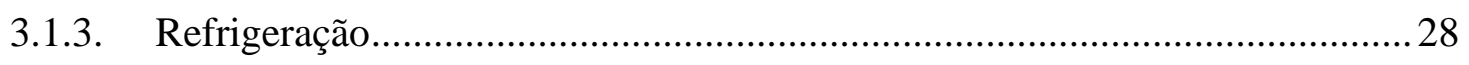

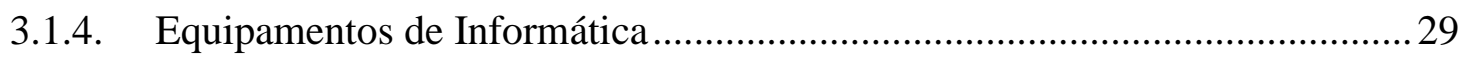

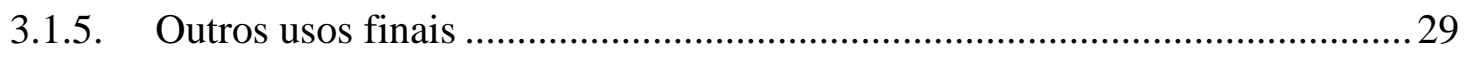

3.2. OBTENÇÃO DO CONSUMO DESAGREGADO ..............................................

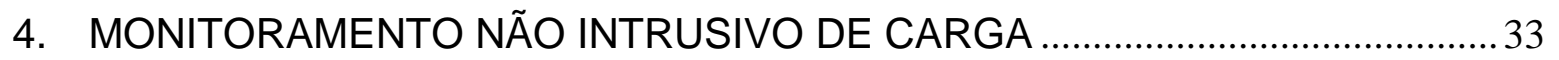

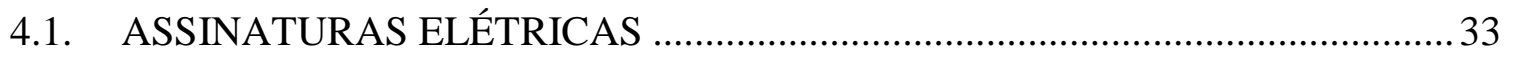

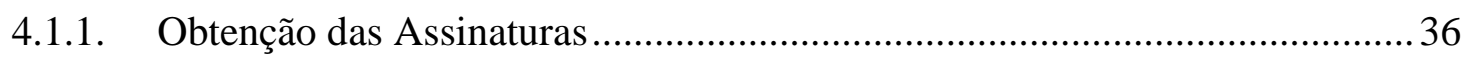

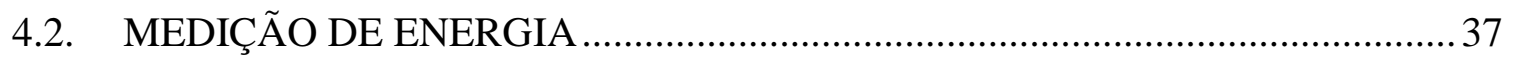

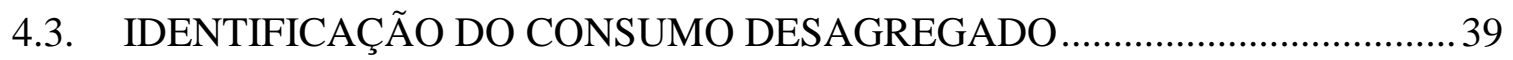

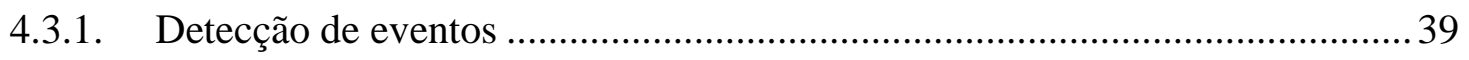

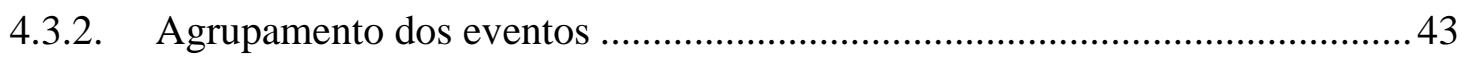

4.3.3. Identificação das Assinaturas Elétricas ........................................................ 44

4.4 BANCOS DE DADOS PUBLICAMENTE DISPONIBILIZADOS ......................... 45

4.4.1. Reference Energy Disaggregation Dataset .................................................. 45

4.4.2. Commercial Building Energy Data Set ....................................................... 46

4.4.3. Outros bancos de dados disponibilizados ..................................................... 47

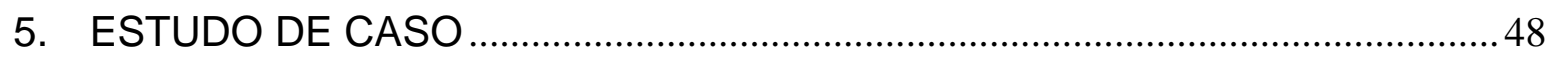

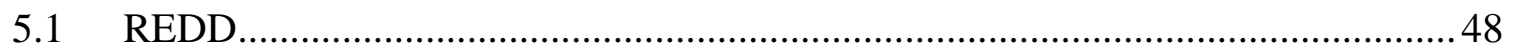

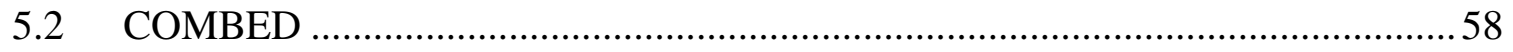

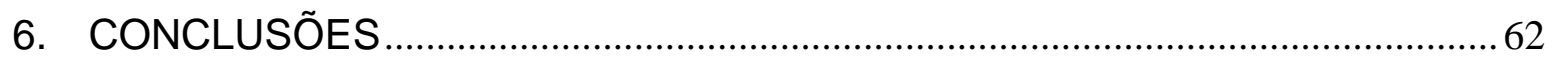




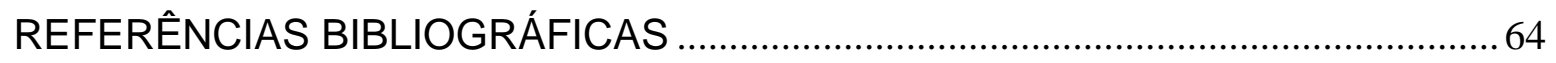




\section{INTRODUÇÃO}

O cotidiano da sociedade moderna inclui diversas atividades associadas ao uso de tecnologia que, dependentes do consumo de energia elétrica, a torna refém deste tipo de insumo. A praticidade e o domínio das técnicas para transformação das fontes de energia primária (solar, eólica, hidráulica, petróleo, etc.) em energia elétrica e esta em algum serviço energético (iluminação, condicionamento ambiental, força motriz, etc.), aliada à facilidade de transmissão da energia elétrica do local de geração até os pontos de consumo, contribuem para que este tipo de insumo esteja difundido em todo o planeta.

Esta série de transformações utiliza diversos meios para atender as necessidades humanas conforme a tecnologia disponível. Primitivamente, utilizavam-se tochas e fogueiras para iluminar e aquecer os ambientes, assim como para a cocção de alimentos. Atualmente tais benefícios são obtidos através de sistemas dedicados, mais eficientes e seguros, como a iluminação a LED, os condicionadores de ar e fogões a gás ou elétricos. Observa-se que nesses casos os serviços energéticos são os mesmos, luz e calor, mas o acionamento desses equipamentos mudou, e continua em constante evolução nos dias de hoje.

A força motriz, por sua vez, também passou por grandes transformações ao longo do tempo, passando do esforço braçal humano para a utilização da força dos animais. As rodas hidráulicas e moinhos de ventos também foram, por muito tempo, utilizados como força motriz sendo substituídos pelas máquinas a vapor, por motores a combustão interna e pelas máquinas elétricas, que também se encontram em evolução.

O setor elétrico, portanto, compõe uma parte de uma moderna cadeia de transformações energéticas visando o bem estar humano e o desenvolvimento de seus processos produtivos. Sabe-se, no entanto, que para cada etapa da transformação há algum tipo de perda energética e impactos ambientais intrínsecos a esses processos. As pesquisas nas academias, indústrias e demais centros de excelência, visam aumentar sua eficiência, melhorando os processos, 
aperfeiçoando a utilização das matérias-primas, enfim, buscam concretizar ferramentas que permitam um uso racional e eficiente da energia.

Programas em nível nacional estabelecem parâmetros e metas, contribuindo amplamente para a melhoria no consumo de energia. O Programa Brasileiro de Etiquetagem - PBE é um exemplo de ação coordenada pelo Instituto Nacional de Metrologia, Qualidade e Segurança - Inmetro que, suportado na Lei de Eficiência Energética - Lei 10.295/2001 que estabelece metas de eficiência mínima e de consumo máximo de energia para diversos tipos de equipamentos (BRASIL, 2001), os classifica de acordo com o desempenho em relação ao consumo de energia de forma a orientar os clientes na hora da compra.

A Etiqueta Nacional de Conservação de Energia - ENCE é concedida aos modelos testados e aprovados, onde, em destaque, é exibida a classificação do produto quanto ao consumo de energia, além de informações técnicas de operação e desempenho, seus dados de identificação e de seu fabricante (INMETRO, 2014).

Aqueles classificados com a letra A são os que, dentro de sua categoria, consomem menos energia, resultado de um maior investimento em pesquisas na sua concepção, na aquisição de matéria-prima de maior qualidade e maior acuidade em sua produção, o que justifica seu custo maior nas lojas. Por outro lado, aqueles classificados com a letra E são geralmente mais baratos, pois utilizam processos antigos, sem inovação tecnológica e com matéria-prima de menor qualidade, mas que, por consequência, acabam demandando maior quantidade de energia em sua operação.

Essa falsa impressão de economia obtida na aquisição de um equipamento classe $E$ se revela paulatinamente nas faturas de energia com um pequeno incremento no seu valor que, ao final da vida útil do aparelho, se torna maior que aquela economia inicial. Comparando com um classe $A$, a economia do equipamento eficiente pode totalizar um montante equivalente ao da compra de um equipamento novo ao fim da vida útil.

Esta classificação visa, portanto, combater a assimetria de informação entre consumidores, que muitas vezes menospreza o custo da energia na aquisição de 
equipamentos, e fornecedores, que podem oferecer produtos melhores a seus clientes, uma vez que suas vantagens ficam evidenciadas.

Dois importantes parceiros do Inmetro no PBE são a Petrobras e a Eletrobrás. A Petrobras provê apoio técnico e administrativo para que, através do Programa Nacional da Racionalização do Uso dos Derivados do Petróleo e do Gás Natural Conpet, se desenvolvam e se integrem medidas visando o uso racional dos derivados de petróleo e gás natural (BRASIL, 1991).

Por sua vez, a Eletrobrás, através do Programa Nacional de Conservação de Energia Elétrica - Procel, coordena a avaliação dos equipamentos quanto ao consumo de energia elétrica, utilizando além de recursos próprios, fundos da Reserva Global de Reversão - RGR e também recursos de entidades internacionais (ELETROBRAS; PROCEL, 2013).

Evidenciando ainda mais as avaliações obtidas no PBE, os selos Procel e Conpet identificam aos consumidores os equipamentos que obtiveram melhores desempenhos dentro de sua categoria, geralmente aqueles classificados com a letra A. Tais selos são concedidos anualmente e visam estimular o desenvolvimento da indústria para oferecer equipamentos cada vez mais eficientes.

Observa-se assim, que há grandes esforços para as indústrias se adequarem a esta realidade, fornecendo produtos e equipamentos de melhor qualidade, de forma que utilizem a energia de forma mais eficiente. Este desenvolvimento favorece a competitividade entre as empresas, contribuindo para reduzir os impactos ambientais nesses processos.

Com grande importância também, a Lei no 9.991/2000, que obriga as concessionárias e permissionárias de serviços públicos de distribuição de energia elétrica a aplicarem 0,75\% de sua Receita Operacional Líquida - ROL em pesquisa e desenvolvimento do setor elétrico e mais $0,25 \%$ da ROL em programas de eficiência energética na oferta e no uso final (BRASIL, 2000), impulsionando ainda mais os investimentos destinados à utilização eficiente de energia. 
Essa lei estabeleceu inicialmente a divisão das porcentagens em $0,5 \%$ tanto para pesquisa e desenvolvimento, quanto para a eficiência energética, até o fim de 2005 (BRASIL, 2000). Em 2007, a Lei no 11.465/2007 estabeleceu novamente essa divisão em $0,5 \%$ para pesquisa e desenvolvimento e também para a eficiência energética até o fim de 2010 (BRASIL, 2007). Em 2010, a Lei noo 12.212/2010 estendeu esse prazo até o final de 2015 (BRASIL, 2010).

Fica evidenciado que muitas ações são realizadas com o intuito de instruir a população sobre a eficiência energética e as ações das indústrias visam fornecer equipamentos que possibilitem a prática da eficiência energética. Cabe ao usuário, avaliar seu consumo atual e verificar se é viável realizar a troca do equipamento, ou de todo o sistema de algum serviço energético.

Muitos fatores influenciam nestas escolhas como o conhecimento do tomador de decisão acerca deste tema, a política de gestão da energia dentro de uma empresa, além do investimento necessário e do tempo de retorno do capital aplicado nesta intervenção.

Quanto ao tempo de retorno, o cálculo não é trivial, uma vez que, é quantificado como função da energia economizada, ou seja, da ausência de consumo, logo não é possível medir diretamente essa quantia (EVO, 2012).

A simples comparação entre o que foi consumido pelo sistema antigo e o recémreformado podem resultar em avaliações equivocadas acerca da medida de eficiência energética realizada. O consumo de energia elétrica em uma instalação depende de uma série de fatores que podem ser constantes, cíclicos ou esporádicos.

Quanto mais se produz em uma fábrica, por exemplo, maior o consumo de energia. Tal aumento no consumo de energia pode, aparentemente, anular o efeito da economia proporcionado pela ação de eficiência energética, gerando a impressão de que a ação não tenha surtido o efeito estimado. A temperatura externa também influencia no consumo de energia em ambientes climatizados. Assim, a identificação dos fatores que afetam o consumo permite que estes efeitos sejam calculados de forma mais precisa. 
A medição individualizada dos equipamentos facilita o modelamento matemático do consumo de energia referente a cada sistema instalado, em função das variáveis que os influenciam. No entanto, dependendo da instalação pode não ser possível instalar tais medidores, seja por falta de acessibilidade, falta de segurança ou até mesmo por não existir um circuito dedicado para cada serviço energético.

Segundo (ALVAREZ, 1998 e BENAVIDEZ, 2014) é comum encontrar instalações sem circuitos de alimentação independentes para os sistemas de ar condicionado e de iluminação, sendo inviável distinguir quanto cada sistema representa no consumo desagregado através da medição direta. LEITE (2010) cita também a dificuldade de encontrar o prontuário atualizado das instalações elétricas nas edificações do Brasil, o que dificulta a identificação dos circuitos a serem monitorados.

Visando identificar o comportamento de consumo de uma determinada instalação, (ROSA, 2007) utilizou algoritmos baseados em regressões lineares que procuram identificar a relação entre o consumo de energia de uma instalação em função da temperatura externa, ou seja, procurava-se identificar a contribuição do sistema de condicionamento ambiental no consumo total, assim como SAIDEL et al. (2006) que identificou que há na Cidade Universitária "Armando de Salles Oliveira" CUASO uma relação muito forte entre o consumo de energia elétrica e a temperatura externa, quando esta ultrapassa os $23^{\circ} \mathrm{C}$, com variação de até 400 $\mathrm{kW} /{ }^{\circ} \mathrm{C}$ na demanda média diária.

Esta informação é muito importante para esta Universidade, pois está relacionada diretamente aos dispêndios de cada ciclo de faturamento. Para a gestão da energia, no entanto, devido à extensão do campus e às características particulares de cada ramo de atividade nas diversas Unidades, são necessários dados mais particulares, para que possam ser comparadas com instalações do mesmo ramo de atividade, ou com valores de referência a fim de avaliar a utilização deste insumo. 
Utilizando dados de consumo de algumas Unidades da CUASO, obtidas através do Sistema de Gerenciamento de Energia na USP - SISGEN e fornecidas pela equipe do Programa Permanente para Uso Racional e Eficiente de Energia na USP - Pureusp, e da temperatura ambiente, fornecidas pelo Instituto de Astronomia, Geofísica e Ciências Atmosféricas da USP - IAG/USP, (KANASHIRO e MAKIYAMA, 2011) identificaram unidades como o prédio da História e Geografia, o de Ciências Sociais e Letras e o da Faculdade de Educação, onde o consumo pouco se altera em relação à temperatura externa, o que é explicado pela ausência ou pouca quantidade de equipamentos de ar condicionado, sendo predominante o sistema de iluminação nessas instalações. Neste mesmo estudo, os autores identificaram unidades como o Instituto de Ciências Biomédicas 1 e 2 e a Faculdade de Medicina Veterinária e Zootecnia, onde a regressão linear entre a demanda e a temperatura em bases horárias apresentaram forte correlação indicando a possibilidade da existência de equipamentos de ar condicionado ou de refrigeração.

Nesse caso, a análise ficou restrita à identificação de instalações com consumo de energia influenciado pela temperatura externa, mas esta metodologia pode se estender para outras variáveis, como a quantidade de unidades produzidas em uma fábrica, frequência de visitação das pessoas em um museu, mas sem identificar um equipamento específico e sim todos os sistemas que são influenciados pelas variáveis utilizadas.

Para caracterizar o consumo de energia nas edificações também são utilizados os indicadores de energia que relacionam as características elétricas, como consumo e demanda, com as características físicas da instalação, como área edificada, ou com algum período específico, como meses de verão e de inverno, períodos letivo e de férias, horários de ponta, fora de ponta e reservado. No caso da Universidade de São Paulo, esses indicadores foram explorados por SAIDEL (2005), FAVATO (2005), MORALES (2007), entre outros, fornecendo subsídios para a gestão da energia, avaliando sua evolução e os resultados dos programas implantados, através de uma abordagem global da instalação, ou seja, a redução do consumo 
por metro quadrado edificado $\left(\mathrm{kWh} / \mathrm{m}^{2}\right)$, redução do consumo no período reservado, entre outros indicadores.

Esses indicadores, no entanto, não conseguem caracterizar os consumos específicos de cada sistema de uma forma precisa. Outros fatores também podem alterar o consumo total de uma instalação sem necessariamente estarem relacionados ao projeto de eficiência energética implantado. A grande vantagem de utilizar o valor do consumo desagregado em usos finais é poder avaliar isoladamente os projetos de eficiência energética quanto ao seu efeito no consumo total de energia.

$\mathrm{Na}$ impossibilidade de realizar a medição direta de cada uso final, sugere-se a utilização da potência instalada e de valores dos fatores de carga e de demanda dos usos finais, onde através de valores médios encontrados em publicações especializadas, ou ainda, em valores consolidados pela prática, calcula-se 0 consumo desagregado e o potencial de economia desses sistemas (ALVAREZ, 1998).

Outra possibilidade de identificação do consumo desagregado é o levantamento dos equipamentos, suas respectivas potências e horas de funcionamento. Esse levantamento foi realizado na USP, no âmbito do Projeto CONSERVUSP, e visava aplicar os conceitos ensinados em salas de aula a respeito do gerenciamento da utilização da energia elétrica, mas que contraditoriamente não eram praticados pela Universidade (SAIDEL, 2005).

O levantamento desses equipamentos ocorreu em 1996 e identificou uma participação de $39 \%$ no consumo total referente aos diversos sistemas de iluminação e 17\% correspondente aos sistemas de condicionamento ambiental. Esses foram os dois usos finais mais significativos observados na época (SAIDEL, 2005). Este método, no entanto, depende dos dados de consumo dos equipamentos e de hábitos dos usuários, que nem sempre se encontram disponíveis ou são precisos, obrigando o pesquisador a estimar essas informações, aumentando a incerteza desse diagnóstico. 


\subsection{OBJETIVOS}

Na pesquisa iniciada nos anos 1980, George W. Hart utilizava dados de potência ativa e reativa medidos a cada segundo, em um ponto central de fornecimento de energia, e visava identificar os instantes de início e fim de operação dos equipamentos pela variação na curva de carga da instalação (HART, 1985). Atualmente, os diversos pesquisadores aplicam diferentes algoritmos buscando identificar os equipamentos através da curva de carga total da instalação como em (AZZINI; TORQUATO; SILVA, 2014; BATRA et al., 2014; PARSON, 2014).

Assim, visando contornar a dificuldade em acessar pontos no interior da instalação para identificar seus consumos desagregados, este trabalho irá analisar diferentes metodologias do Monitoramento Não Intrusivo de Carga, do inglês Non Intrusive Load Monitoring (NILM, na sigla em inglês e que será utilizada neste trabalho), para fornecer uma ferramenta que possibilite uma gestão energética mais precisa e menos dispendiosa.

\subsection{ESTRUTURA DO TRABALHO}

Desta maneira, este trabalho fica estruturado com a justificativa, introdução ao tema e objetivos no Capítulo 1.

A gestão da energia e sua importância para o desenvolvimento deste trabalho são abordadas no Capítulo 2.

A utilidade do consumo desagregado na gestão de energia é tratada no Capítulo 3.

As metodologias de NILM para obter o consumo desagregado são abordadas no Capítulo 4.

No Capítulo 5 é realizado um estudo de caso no prédio da Engenharia Elétrica da Escola Politécnica da USP.

No Capítulo 6 estão as conclusões do trabalho e sugestões para prosseguimento da pesquisa. 


\section{GESTÃO DE ENERGIA}

Uma vez que o emprego de energia elétrica está presente nos mais variados segmentos, seja na produção de bens, na prestação de serviços, ou no bem-estar humano, sua utilização deve ser realizada de forma racional e eficiente. Diante das inúmeras possibilidades de se beneficiar do consumo da eletricidade, cada setor deve ser abordado de maneira distinta, estabelecendo metas de consumo específicas de seu ramo de atividade, de acordo com a localidade, o clima da região, características do entorno, disponibilidade de recursos, entre outros.

Observa-se que não existe uma cultura de gestão de energia por parte dos usuários. Suas ações são geralmente reativas ao detectar um grande aumento nas faturas, como apagar algumas das lâmpadas de um ambiente e restringir o tempo de utilização de certos equipamentos, visando adequar o custo final ao orçamento disponível. Estas ações, no entanto, são gradualmente suplantadas pelos antigos hábitos se refletindo aos poucos nas faturas de energia, até que se observe a necessidade de reduzir os custos novamente.

Cabe ressaltar que, toda medida tomada visando reduzir o consumo de energia deve, no mínimo, preservar a qualidade do serviço energético, mantendo-o adequado ao propósito a que se destina. É inviável para a sociedade moderna abrir mão dos benefícios oferecidos pelo uso da tecnologia, pois reflete diretamente no desempenho de suas atividades cotidianas tanto de lazer, quanto profissionais. Um nível de iluminação adequado, por exemplo, assegura uma sensação de bem-estar, possibilita a realização de tarefas visuais, rápida e precisamente e proporciona segurança visual, ao olhar ao redor e detectar perigos (ABNT, 2013).

Assim, faz-se necessário monitorar o serviço energético obtido, uma vez que o consumo de energia é consequência da demanda por tais benefícios. A gestão de energia analisa tais variáveis visando aperfeiçoar a utilização da energia elétrica e também de outros insumos e "pode ser conceituada como um conjunto de fundamentos, técnicas e ferramentas de ordenamento e conservação de energia, visando seu aproveitamento ótimo em bases sustentáveis" (SAIDEL, 2005, p. 29). 
Diante desta situação, cabe à engenharia convencer os tomadores de decisão que aplicar recursos humanos e financeiros em eficiência energética pode ser vantajoso economicamente para a empresa. Além da recuperação do capital investido, proporcionado pela redução no valor da fatura desse insumo, benefícios indiretos poderão reforçar os argumentos em favor das ações de eficiência energética.

A divulgação dessas ações demonstra o alinhamento da empresa com a filosofia do desenvolvimento sustentável, agregando valor à sua marca e aos seus produtos, e que pode representar um diferencial na preferência dos consumidores.

Por ser um mercado pouco explorado no Brasil e com resultados ainda questionados pelos investidores, uma demonstração bem estruturada das economias proporcionadas por essas ações pode ser decisiva na implantação de processo de eficiência energética.

Assim, para realizar uma boa gestão do consumo de energia é necessário quantificar sua utilização de forma precisa, permitindo que seus valores sejam modelados de acordo com as características de seu uso. A estruturação do consumo permite que a eficiência energética de uma instalação possa ser comparada a si própria, porém em uma condição operacional distinta.

A nova condição pode ser devida tanto à sazonalidade, ou seja, diferentes necessidades energéticas para cada época do ano, que naturalmente provocam alterações no consumo, como também pela substituição dos equipamentos utilizados, proporcionando os mesmos serviços energéticos, porém de forma mais eficiente.

\subsection{SISTEMAS DE GESTÃO DE ENERGIA}

Até a criação da norma ISO 50001, em 2011, não existiam modelos internacionais para a gestão específica da energia elétrica. Conforme constatação de Favato e 
Pinto (2009), as análises partiam de outras áreas da engenharia, como a de produção e de qualidade.

Os conceitos adotados na norma ISO 50001 são recorrentes de especificações e regulamentações de diversos países, e assim como as demais normas ISO, facilita as negociações, dissemina o conhecimento e avanços inovadores em tecnologia e compartilha as boas práticas de gestão. (ISO, 2011)

Esta norma provê, a todos os setores da economia, estratégias para aumentar a eficiência energética de sua instalação utilizando uma estrutura de gestão reconhecida internacionalmente. Baseada em conceitos comuns de outras normas ISO, a ISO 50001 pode ser facilmente integrada à ISO 9001 e à ISO 14001, sistemas de gestão de qualidade e de gestão ambiental, respectivamente.

Sua estrutura é fundamentada no ciclo de melhoria contínua conhecido pela sigla em inglês PDCA, de Plan-Do-Check-Act, onde através destes quatro passos (Planejar, Executar, Verificar e Agir) procura tornar mais claros os processos envolvidos no sistema de gestão energética.

A fase de Planejamento envolve o estabelecimento de metas e as metodologias de acompanhamento dos resultados, de acordo com a política energética adotada na empresa. São definidos os indicadores de consumo energético e a linha de base, que retratam o desempenho energético da instalação e é elaborado o Plano de Ação com as atividades necessárias para atingir tais metas.

O Plano de Ação é implantado na etapa de Execução.

$\mathrm{Na}$ etapa de Verificação os resultados são medidos e comparados com os objetivos iniciais. As não conformidades e possíveis correções dos processos são observadas nesta etapa.

A etapa Agir se caracteriza por manter a política de melhoramento contínuo do desempenho energético, sendo um elo entre um ciclo e o seguinte, visando perpetuar a cultura em eficiência energética.

A figura 1 a seguir, ilustra de forma mais detalhada as etapas do Sistema de Gestão de Energia. 


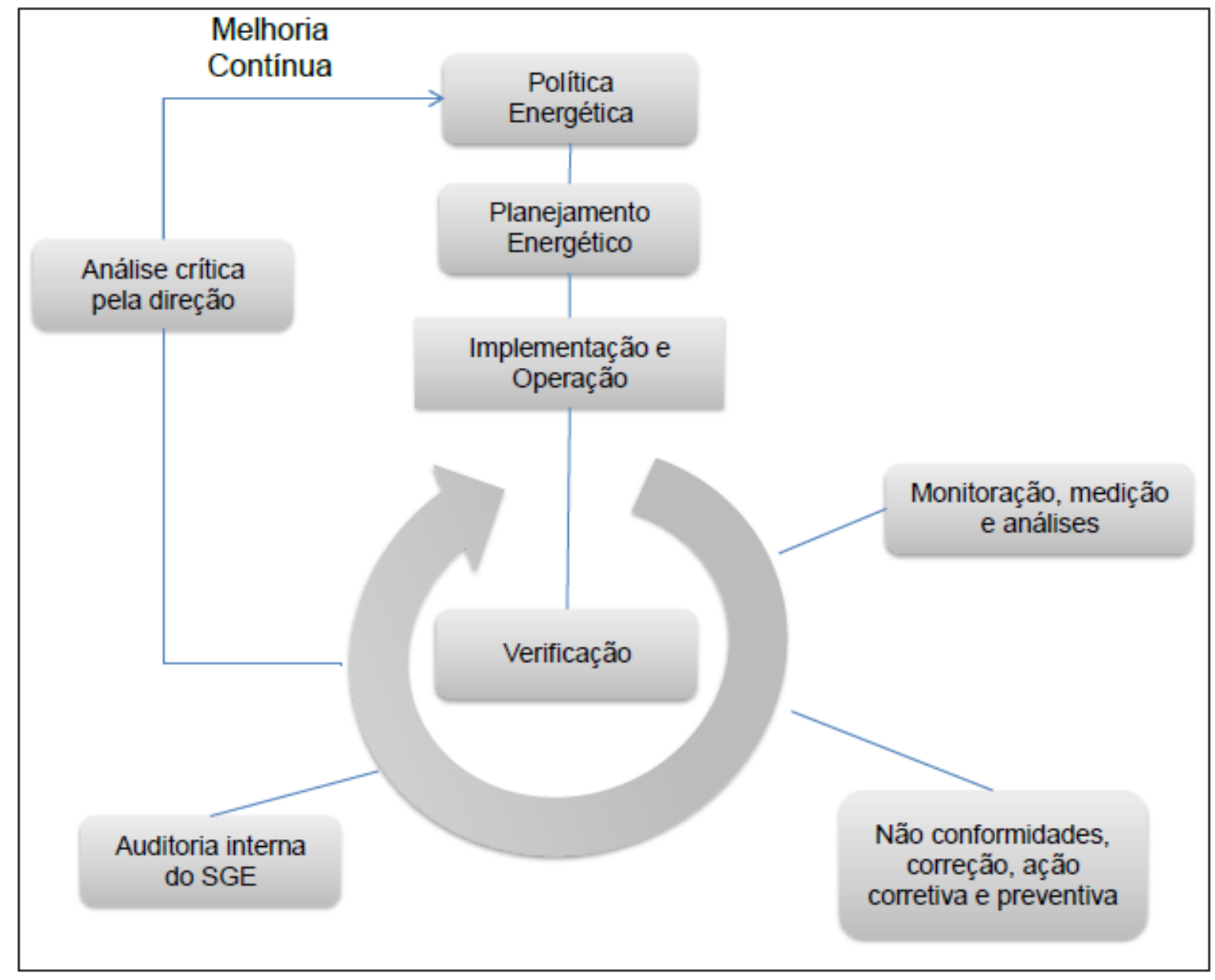

Figura 1 - Estrutura do Sistema de Gestão de Energia

Fonte: Adaptado de ABNT, 2011.

A visão de longo prazo confere ao investidor a possibilidade de ganhos futuros maiores do que outras aplicações para este capital. As reduções dos custos com a energia elétrica, em muitos casos, possuem curto período de retorno de capital, transformando-se em "lucro" após esse período.

Uma vez que o consumo de energia elétrica em uma instalação tende a crescer conforme as novas necessidades vão surgindo, as aquisições dos novos equipamentos deverão estar acompanhadas de uma avaliação acerca do consumo de energia e seus indicadores, o que permite minimizar o acréscimo de energia dos novos equipamentos. 
A implantação de um sistema eficiente, desde o início, geralmente produz resultados melhores que uma instalação antiga que passa por uma readequação. Um retrofit no sistema de iluminação, por exemplo, pode reduzir a quantidade de pontos necessários para iluminar o ambiente de forma adequada. Assim, os pontos deverão, quando possível, serem reposicionados para manter a uniformidade da iluminação.

As Metodologias de Gestão de Energia estabelecem parâmetros e orientações para que as avaliações sejam mais bem aceitas universalmente e que ao serem adotadas podem ser utilizadas como base de negociação em casos de contratação de serviço das Empresas de Serviços Energéticos (ESCOs) e também quanto aos créditos de Carbono.

Aplicável para todos os tipos de instalação, a norma ISO 50001 visa estabelecer uma rotina de melhoria contínua no uso da energia, reduzindo seus custos e aumentando sua eficiência.

Sem estipular uma meta específica, a ISO 50001 propõe a utilização de indicadores de consumo, monitorados permanentemente, visando manter a instalação em um estado elevada eficiência no consumo de energia.

Utilizar energia eficientemente auxilia as empresas na economia de recursos financeiros, assim como na preservação dos recursos naturais e no combate as mudanças climáticas. A ISO 50001 auxilia empresas de todos os setores a utilizar energia mais eficiente através do desenvolvimento de um Sistema de Gestão de Energia. Por estar baseada em modelos de melhoramento contínuo, já utilizados por outras normas como a ISO 9001 e a ISO 14001, facilita sua integração aos sistemas de gestão de qualidade e de gestão ambiental.

Esta norma foi desenvolvida de forma a permitir sua aplicação em todo tipo de instalação, seja residencial, comercial ou industrial, e contou com a colaboração de especialistas de diversos segmentos (fabricantes, consumidores, acadêmicos, etc.).

A norma ISO 50001 cita a melhoria contínua como forma de gestão. Na prática ela sugere que esses indicadores sejam permanentemente monitorados de forma a 
identificar as possibilidades de economia de energia na instalação e sempre que possível atuar de forma a reduzir seu consumo de energia.

\subsection{PROTOCOLO INTERNACIONAL DE MEDIÇÃO E VERIFICAÇÃO DE DESEMPENHO ENERGÉTICO}

Visando descrever as características necessárias para que essa estruturação seja aceita de forma ampla e universal foi elaborado o Protocolo Internacional de Medição e Verificação de Desempenho Energético - PIMVP, que conta com a colaboração de membros de instituições distribuídas por diversos países, para sua constante atualização.

Publicado pela primeira vez com o nome de North American Energy Measurement and Verification Protocol (Protocolo Norte Americano de Medição e Verificação de Energia) em 1996, e intitulado de International Performance Measurement and Verification Protocol - IPMVP (Protocolo Internacional de Medição e Verificação de Performance - PIMVP) no final de 1997, este documento contém um modelo de padronização das terminologias e das boas práticas para se documentar as economias de energia obtidas pelas Ações de Eficiência Energética - AEE, através de Planos de Medição e Verificação - M\&V (EVO, 2012).

Uma vez que cada projeto é único para cada instalação, o Plano de M\&V também deverá ser elaborado de acordo com cada necessidade de um novo projeto. Apesar de ser bastante flexível, de modo a se ajustar a cada projeto individualmente, o relatório de determinação de economia deverá ser transparente o suficiente para que não restem dúvidas acerca de seus valores, com cada medição e estimativas devidamente documentadas e justificadas.

O PIMVP não é uma norma, logo, não existe um modelo formal desta documentação, mas ele apresenta princípios e termos comuns amplamente aceitos como a base de um bom processo de M\&V, assim como, fornece métodos com diferentes níveis de custo e exatidão visando determinar as economias, seja de toda instalação, seja de cada ação de eficiência energética avaliada 
isoladamente. Esta conciliação entre uma precisão razoável e custo aceitável é um aspecto-chave na concepção do Plano de M\&V. (EVO, 2012)

Visando solidificar sua aceitação, as boas práticas de Medição e Verificação se alinham aos seguintes princípios:

A Completude ao reportar a economia, onde todos os efeitos devem ser considerados em seus relatórios, com medições para quantificar aqueles julgados significativos e com estimativas na determinação dos demais.

O Conservadorismo que deverá ser aplicado quando valores incertos forem utilizados na emissão de pareceres. Nesses casos o procedimento de cálculo deverá avaliar por baixo o valor das economias.

A Consistência entre relatórios de diferentes relatores ou de projetos distintos, nos quais devem apresentar áreas-chave compatíveis com o plano de M\&V.

A Precisão dos resultados que devem ser tão elevadas quanto se permite 0 orçamento. Já os custos da M\&V devem ser pequenos se comparado ao seu retorno monetário.

A Relevância, onde as variáveis importantes e críticas devem ser medidas enquanto que as previsíveis e menos críticas podem ser estimadas.

E a Transparência, onde todos os passos devem ser claros e completamente divulgados.

\subsubsection{Estrutura do PIMVP}

A economia de energia representa o quanto se deixou de consumir após uma determinada AEE. Por ser resultado de uma ausência de consumo, esta economia não pode ser medida diretamente. Já a simples comparação do consumo medido antes da AEE, chamado de linha de base, e após sua implantação, pode apresentar diferenças significativas entre as condições de operação nesses dois momentos distintos, e que naturalmente iriam alterar o perfil de consumo independentemente de qualquer ação realizada na instalação. Assim, essa comparação deverá ser complementada com um valor de ajuste, positivo ou negativo, que irá estimar qual seria o consumo de energia na ausência da AEE. 
A figura 2 representa um processo de determinação de economia em uma AEE de recuperação do calor dos gases emitidos em uma caldeira industrial. Observa-se que após a implantação dessa $\mathrm{AEE}$, houve também um aumento na produção desta fábrica. Assim, a determinação da economia deve partir do patamar de consumo que o aumento na produção iria demandar sem a implantação da AEE. Esse ajuste visa isolar o efeito do aumento da produção que interfere, neste caso, negativamente no impacto da AEE, subestimando a economia obtida.

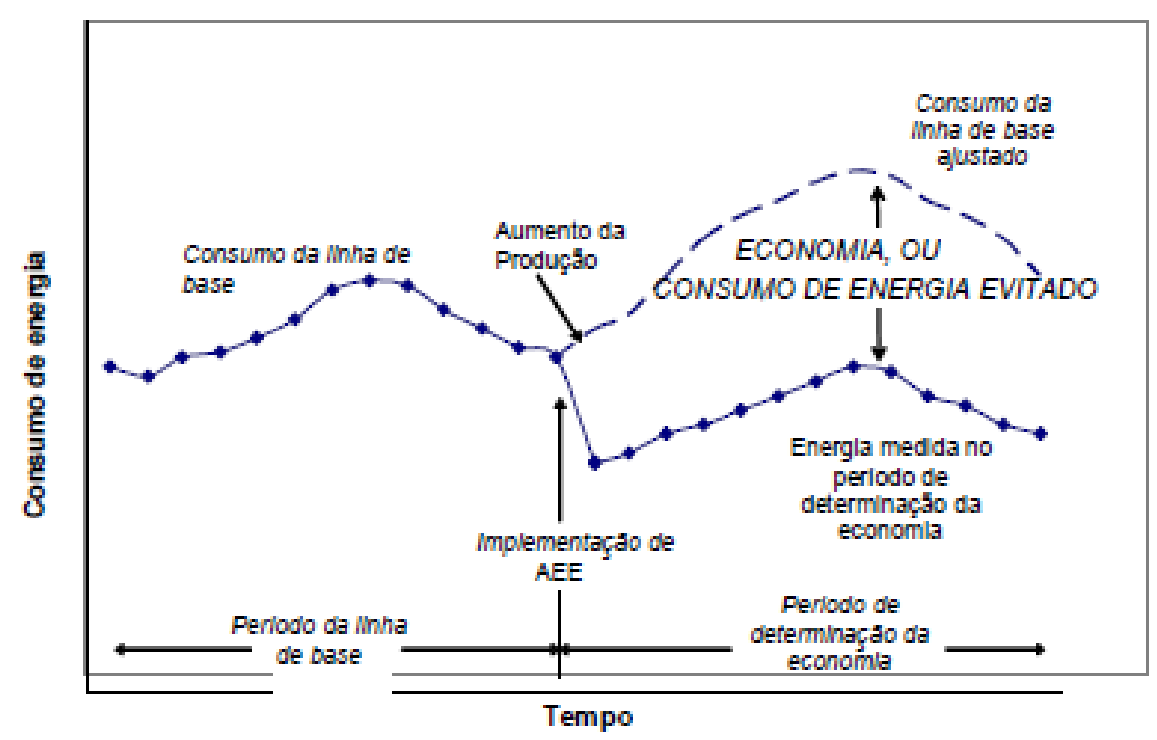

Figura 2 - Exemplo de um processo de determinação da economia.

(Fonte: EVO, 2012)

"É necessário separar os efeitos energéticos de um programa de economia dos efeitos de outras mudanças simultâneas, responsáveis por afetar os sistemas que usam energia" (EVO, 2012 p. 8). Mudanças no clima, ou na produção de uma fábrica naturalmente alteram o consumo de energia de uma instalação sendo necessário utilizar um valor de ajuste para que os consumos da linha de base e do período de determinação da economia sejam avaliados sob um conjunto equivalente de condições.

Desta maneira, a equação geral de determinação de economia proposta pelo PIMVP fica caracterizada pela seguinte combinação de elementos: 
Economia $=($ Consumo no período da linha de base - Consumo no período de determinação da economia) \pm Ajustes

Fonte: EVO, 2012.

Segundo (EVO, 2012), "O termo 'ajustes' faz a distinção entre economias reais e simples comparação de custos". No caso das condições climáticas e da produção em uma fábrica essa parcela é chamada de ajuste de rotina.

Os ajustes de rotina são fatores que influenciam o consumo de energia e que variam periodicamente. Os modelos matemáticos preveem essas alterações e seus impactos no consumo de energia.

Segundo recomendações do PIMVP, para determinar as quantidades de energia da Equação (1) podem ser utilizados um ou mais dos seguintes meios:

- A fatura da concessionária, ou leitura de seu medidor;

- Medidores parciais que isolam a AEE;

- Medições separadas dos parâmetros utilizados no cálculo de consumo de energia, como período de funcionamento e características da carga elétrica dos equipamentos;

- Medição de representantes (proxies ${ }^{1}$ ) comprovados de consumo de energia, no caso de existir uma variável que seja correlacionada a esse consumo, ela poderá ser monitorada para quantifica-lo;

- Simulação por computador calibrada com dados reais de desempenho energético.

Dependendo do tipo AEE implantado, de seu respectivo cálculo de economia e precisão necessária um tipo de medição deverá ser adotado. Esta escolha dependerá também de qual das quatro opções do PIMVP, descritas a seguir, são mais adequadas para cada caso.

\footnotetext{
1 "Por exemplo, se o consumo de energia de um motor for correlacionado com o sinal de saída do variador de velocidade que controla este motor, o sinal de saída poderá ser um representante comprovado para a energia
} 
Uma possibilidade de avaliação das economias de energia de maneira simplificada é com a utilização da Opção $A$, que monitora a AEE de forma isolada e possui aplicação típica onde a intervenção altera apenas a potência ou apenas o período de funcionamento de um sistema. Essa característica que foi alterada é definida como parâmetro-chave e deverá ser medida. Já o outro parâmetro poderá ser estimado, baseado em dados históricos, especificações dos fabricantes ou avaliação de engenharia.

Quando não é possível realizar tal estimativa de maneira confiável, utiliza-se a Opção $B$ que também monitora a AEE de forma isolada, porém com a medição em campo de todos os parâmetros. Esta Opção é indicada nos casos que se alteram tanto a potência, quanto o período de funcionamento dos sistemas e a definição de seus valores se tornam incertas.

Nessas duas opções, o monitoramento isolado da AEE delimita uma fronteira de medição mais estreita, permitindo avaliar com menos interferências os efeitos dessa intervenção. No entanto, as fugas de energia através de efeitos interativos não monitorados devem ser avaliadas, pois podem afetar significativamente outros sistemas, alterando o valor real da economia.

O retrofit do sistema de iluminação, por exemplo, além de reduzir sua demanda de energia, reduz também a quantidade de calor liberado no ambiente, diminuindo a carga de resfriamento do sistema de ar condicionado, ou eventualmente aumentando a necessidade de calefação no inverno. Se forem considerados significativos e a fronteira de medição não puder englobar esses efeitos interativos, estimativas poderão ser feitas como fração da economia de energia de iluminação calculada, ajustada para cada estação do ano.

De modo mais abrangente, a Opção $C$ do PIMVP, avalia o consumo de energia de toda a instalação e é mais indicada em casos de múltiplas AEEs, com efeitos interativos entre si, tornando mais difícil a avaliação isolada de cada uma. Para utilização desta Opção, no entanto, recomenda-se que a economia estimada seja significativa e ultrapasse $10 \%$ do consumo da linha de base para que a discriminação da economia seja feita com confiança. (EVO, 2012) 
Em qualquer das opções, principalmente quando os períodos de determinação de economia são mais longos, podem ocorrer alterações nos sistemas ou estruturas prediais que deverão reajustar a linha de base. São fatores que influenciam o consumo, mas que não se espera que mudem habitualmente como a área climatizada e o número de turnos de produção em uma fábrica. São chamados de Fatores Estáticos e corrigem a linha de base através dos ajustes não-de rotina e constituem um grande desafio para os processos de $M \& V$, em especial para a Opção C.

Inspeções periódicas nos equipamentos e nas operações da instalação deverão ser realizadas para assegurar que eventuais alterações nos fatores estáticos não afetem o valor das economias referentes às AEEs.

Caso não seja possível realizar alguma das medições de energia necessárias, uma simulação calibrada do consumo de energia pode ser utilizada para avaliar as economias. Trata-se da Opção D do PIMVP. Ela utiliza um software para modelamento da instalação, antes e depois da implantação das AEEs e utiliza uma medição real para calibrar o modelo, seja essa medição pré ou pósimplantação da AEE.

A modelagem e a calibração precisas na simulação do consumo constituem o maior desafio associados à Opção D. A simulação deve prever razoavelmente os padrões de consumo de energia da instalação e deve ser calibrado com dados reais de consumo de energia, de variáveis independentes e fatores estáticos.

Ela pode ser utilizada de forma semelhante à Opção $\mathrm{C}$, na determinação da economia de toda a instalação, mas também pode estimar, em caso de múltiplas AEEs, a economia relacionada a cada uma.

$A$ avaliação isolada das $A E E s$, de forma semelhante às Opções $A$ e $B$, também podem ser simuladas pela Opção $D$, entretanto será necessária a instalação de medidores de energia de acordo com as recomendações para utilização dessas opções.

A medição do consumo de energia individualizado de cada sistema pode auxiliar na avaliação dos efeitos interativos. A implantação de pontos adicionais de 
medição, no entanto, implica em aumento do custo do processo de M\&V. Esse aumento de custo, portanto, deverá ser compensado pela maior precisão no cálculo e redução de suas incertezas, proporcionando maior retorno para as economias obtidas. $O$ custo dessa implantação também pode ser rateado com outros projetos de gestão e em longo prazo que poderão amenizar esse impacto financeiro.

Diante desta situação, cabe ressaltar que nem sempre é possível realizar a medição dos sistemas de forma individualizada. Como foi observado por (ALVAREZ, 1998) e (BENAVIDES, 2014), muitas instalações não possuem seus circuitos segmentados pelos usos finais, sendo comum encontrar o sistema de condicionamento ambiental e o de iluminação artificial compartilhando o mesmo circuito.

Outras considerações que podem ser feitas são em relação à falta de identificação dos circuitos de alimentação e à indisponibilidade de um local seguro para instalação de um medidor de energia. Nem sempre existe a identificação do setor ou do sistema que um circuito alimenta. Os quadros de distribuição são muitas vezes instalados em locais com grade circulação de pessoas, que por curiosidade ou falta de conhecimento podem se acidentar ao tocar nos circuitos de medição sem os devidos procedimentos de segurança. 


\section{CONSUMO DESAGREGADO DE ENERGIA}

Conhecer a quantidade de energia consumida por cada equipamento é a situação ideal para o gestor de energia de uma instalação. Essa condição permite saber quais sistemas apresentam os maiores consumos e, associados às tecnologias utilizadas, avaliar o potencial de economia desses sistemas.

Um mau funcionamento dos equipamentos poderá ser detectado através do consumo desagregado. Seja pela elevação no consumo de um refrigerador, causado por desgaste da borracha de vedação da porta, ou por falta de consumo em um complexo sistema de condicionamento ambiental, indicando uma falha no acionamento de algum componente.

O indicador de consumo de energia dividido pela área construída de uma edificação, geralmente é o mais simples de se calcular, permitindo que instalações de tamanhos diferentes possam ser comparadas. No entanto, a simples comparação de consumo de energia elétrica entre instalações distintas, ainda que ponderadas pela área, nem sempre representa com fidelidade quanto uma é mais eficiente que a outra. Cada tipo de atividade desenvolvida necessita de um serviço energético diferente, que por sua vez, demanda uma quantidade específica de energia.

De forma mais detalhada, a identificação dos períodos de utilização desses equipamentos deve ser avaliada, pois a demanda máxima da instalação também é passível de cobrança por parte das concessionárias. Ou seja, utilizar muitos equipamentos no mesmo instante, mesmo que por pouco tempo, também aumenta os custos com a energia elétrica. Assim, a possibilidade de distribuição mais uniforme da utilização dos equipamentos ao longo do dia, torna-se uma forma de reduzir dispêndios com eletricidade.

\subsection{USOS FINAIS DE ENERGIA ELÉTRICA}

As informações sobre o consumo desagregado possibilitam que novos indicadores sejam calculados, tornando a gestão desse insumo mais precisa e a comparação com outras instalações mais coerente. No entanto, cabe ressaltar que um mesmo 
serviço energético pode ser necessário com intensidades distintas para cada tipo de atividade, sendo necessário avaliar cada caso.

\subsubsection{Sistemas de lluminação}

O objetivo da iluminação é proporcionar condições para que as tarefas cotidianas possam ser executadas com precisão e segurança. Conforme disponível na Norma de lluminação de Ambientes de Trabalho (ABNT, 2013), trabalhos que exigem maior acuidade visual, por exemplo, necessitam de maiores níveis de iluminância. Locais de passagem como corredores e saguão de entrada, menos. Nesses casos, além do consumo desagregado para o sistema de iluminação, a atividade desenvolvida também deve ser considerada na avaliação.

Níveis inadequados de iluminância podem provocar fadiga e diminuição da sensibilidade visual, devido ao esforço demasiado para adaptação a estas condições (PROCEL, 2011). Isso reflete no bem estar dos usuários, assim como em sua produtividade.

Cabe ressaltar que este é um serviço energético essencial e grande consumidor de energia elétrica. Estima-se que, no Brasil, a iluminação seja responsável por aproximadamente $23 \%$ do consumo residencial, $44 \%$ no setor comercial e de serviços públicos e 1\% no setor industrial (PROCEL ELETROBRAS, 2007).

Um bom sistema de iluminação deve, portanto, prover níveis adequados de luminosidade, com alta eficiência energética, visando reduzir seu custo operacional. As pesquisas realizadas visam aumentar a eficiência e a qualidade não apenas das lâmpadas, mas de todo o sistema. Os reatores eletrônicos, por exemplo, consomem menos energia que os antigos eletromagnéticos, reduziram a cintilação luminosa e são mais silenciosos e mais leves.

Já as luminárias, deixaram de ser apenas um suporte para as lâmpadas e reatores e passaram a desempenhar um papel muito importante nos projetos luminotécnicos. A utilização de calhas reflexivas nas luminárias permitiu redirecionar parte dos raios luminosos que incidiam em sua própria estrutura para as áreas de interesse, aumentando o fluxo luminoso no plano de trabalho. No caso 
das lâmpadas tubulares, o diâmetro também influencia no rendimento da luminária, como pode ser observado na figura 3 , a seguir.
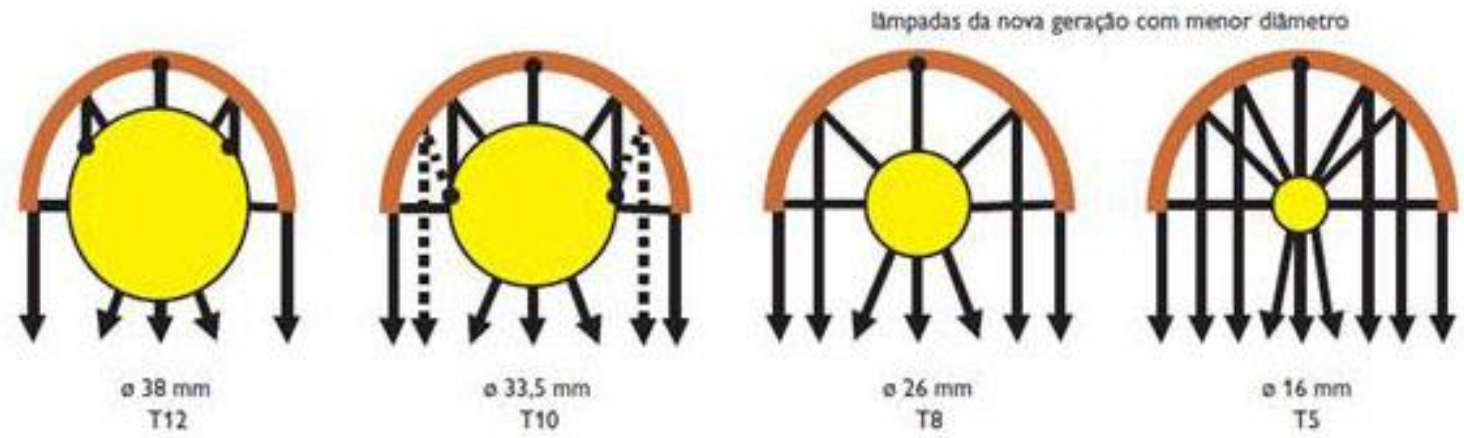

Figura 3 - A influência do diâmetro da lâmpada no rendimento da luminária.

FONTE: PHILIPS ${ }^{2}$.

É desejável, também, que a iluminação natural seja aproveitada e que esta seja realizada de forma integrada ao sistema artificial, com a possibilidade de dimerizar, ou apagar as lâmpadas mais próximas às janelas, de forma independente das demais. O aproveitamento deve, no entanto, evitar a incidência da radiação direta, pois acarreta em um ganho de calor no ambiente, exigindo maior consumo de energia pelos sistemas de condicionamento ambiental. A luz difusa deve ser priorizada, visando equilibrar a utilização de ambos os sistemas.

Convém ressaltar que toda essa infraestrutura representa apenas o potencial de eficiência energética. $O$ uso adequado desse sistema é que determinará a economia de energia efetiva, cabendo ao usuário utiliza-lo de acordo com o projetado (ELETROBRAS PROCEL, 2013). É interessante, portanto, avaliar não apenas o consumo desagregado de tal sistema, como também sua curva de carga com dados de início e término de operação, dimerizações, desligamentos automáticos e manuais.

Uma vez que nem sempre é possível realizar medições segmentadas por usos finais, os algoritmos de Monitoramento Não Intrusivo de Carga possibilitam obter as informações acerca dos períodos de utilização desses sistemas.

\footnotetext{
${ }^{2}$ Disponível em < http://www.lighting.philips.com.br/>, acesso em março de 2015.
} 
Cabe ressaltar que, a utilização de equipamentos cada vez mais eficientes dificulta a detecção dos eventos, ligar e desligar, das lâmpadas, pois sua potência pode ser menor que o limite utilizado pelos algoritmos para que uma variação de energia seja considerada como um evento e não um ruído. Tal dificuldade, no entanto, é desejável, pois significa um menor consumo de energia por esse sistema. Um fato que ameniza esse "problema" é o acionamento único para um grupo de luminárias, muito comum e conveniente para ambientes de maiores dimensões, desde que segmentados segundo recomendações para integração com a iluminação natural.

O controle variável das cargas, como a dimerização da iluminação, ainda é um grande desafio para os algoritmos de detecção do consumo desagregado, assim como a avaliação de uma grande quantidade equipamentos em operação na instalação.

\subsubsection{Condicionamento Ambiental}

O condicionamento ambiental é um serviço energético cuja função é manter a temperatura e a umidade de um ambiente em níveis adequados de conforto aos usuários, ou de acordo com as necessidades de um processo produtivo. Principalmente em edifícios comerciais, mas também em alguns segmentos industriais, seu custo operacional pode ser bastante significativo, e chega a representar $60 \%$ do total de energia consumida pela instalação (PROCEL ELETROBRAS, 2007).

Devido ao seu elevado consumo, o sistema de condicionamento ambiental deve, desde sua fase de projeto, contemplar aspectos do uso racional e eficiente de energia. Os requisitos necessários, dimensionamento do sistema, quantidade de ar externo para renovação mantendo a qualidade do ar interno, entre outras características.

A estrutura da edificação a ser climatizada também influencia no consumo de energia do sistema de condicionamento ambiental. A transmissão térmica de sua envoltória deve ser mínima para evitar ganhos de calor do ambiente externo. Aplicar isolamento nos telhados e paredes reduz a transmissão de calor para 0 
interior desses ambientes, reduzindo o consumo de energia no sistema de condicionamento ambiental.

Os ganhos de calor por insolação também afetam o consumo de energia da instalação. Telhados e paredes com cores claras refletem mais a luz solar e retém menos calor em sua estrutura, transmitindo menos calor para o interior da instalação. A incidência de luz solar no interior do ambiente, apesar de sua contribuição para a iluminação, acarreta em ganhos térmicos muitas vezes indesejados. A instalação de persianas externas ou brises nas janelas reduz a carga térmica, porém aumenta a necessidade de utilização da iluminação artificial. Como já citado anteriormente, uma combinação entre tais sistemas deverá ser encontrada visando aproveitar seus benefícios sem aumentar demasiadamente 0 consumo do outro.

Por ser projetado para climatizar um ambiente específico, recomenda-se 0 fechamento de portas e janelas quando este sistema se encontra em operação. A infiltração de ar e umidade de outros ambientes, internos ou externos, através de portas ou janelas abertas, ou frestas mal vedadas pode aumentar o consumo de energia desse sistema.

Os equipamentos no ambiente também são fonte de calor e por isso devem ser utilizados de forma eficiente e racional. O sistema de iluminação, por exemplo, deve ser projetado com as especificações mínimas recomendadas em norma, garantindo o conforto dos usuários. Uma iluminação excessiva, além de consumir mais energia, pode ofuscar a visão dos usuários, além de aumentar a carga térmica no ambiente, exigindo mais do sistema de climatização.

Quanto à manutenção desse sistema, recomenda-se manter limpos os filtros das tubulações de água gelada e quente, manter os filtros de ar em ótimas condições, reparar todas as fugas de fluidos (ar, água gelada, refrigerante, óleo, etc.), entre outras práticas que visam reduzir as perdas do sistema, evitando um consumo energético excessivo durante seu funcionamento (PROCEL ELETROBRÁS, 2007). 
O monitoramento do consumo desse sistema permite a avaliação de seu custo de operação e os impactos das melhorias quando realizadas em seus equipamentos. A operação desses sistemas, no entanto, pode ser muito complexa, com diversos equipamentos atuando de maneira independente, com regulagens próprias, dificultando a avaliação dos equipamentos.

Existem diversas tecnologias disponíveis para obter esse serviço energético, com diferentes níveis de eficiência e capacidade. Desde soluções autônomas como os equipamentos tipo janela, split e self-contained, até as grandes capacidades, atendendo múltiplos ambientes como os chillers.

A operação e controle desses sistemas pode se tornar muito complexa com o aumento da capacidade necessária. Cada modelo possui um modo particular de operação, com diferentes controles e perfis de consumo de energia.

\subsubsection{Refrigeração}

Muitas instalações possuem a refrigeração como uso final mais importante em suas atividades. Seja para manter os alimentos em uma cozinha, seja para conservar medicamentos ou componentes sanguíneos em hospitais, este uso final presenta elevado consumo de energia ao longo do dia e é intensificado pela necessidade de frequentes aberturas durante as atividades em hospitais e restaurantes.

Tanto em aparelhos domésticos, quanto em grandes sistemas industriais, a correta manutenção deste equipamento deve ser considerada tanto para extensão da vida útil, quanto para a economia de energia. O ressecamento das borrachas de vedação, ou eventuais fugas dos gases refrigerantes aumentam o consumo de energia deste sistema.

Como citado anteriormente, a detecção de um aumento no consumo deste sistema pode ser um indício de mau funcionamento de algum componente. 


\subsubsection{Equipamentos de Informática}

Atualmente, os sistemas de informática presentes em muitas atividades, e com grande intensidade, também merecem atenção especial na avaliação do consumo desagregado de energia. Os usuários muitas vezes não o desligam em períodos de ausência prolongada, e nem desligam os monitores nas pausas mais curtas. Não é tarefa difícil ajustar o gerenciador de energia para um modo econômico, onde na ausência de atividade, ou seja, sem comandos a partir do teclado ou do mouse, o próprio computador vai desligando seus periféricos, inclusive a si mesmo nas ausências prolongadas.

Existem também os equipamentos ficam ligados 24 horas por dia como servidores, switches e no-breaks, que apesar de serem de baixa potência, seu consumo é permanente.

\subsubsection{Outros usos finais}

Entre outros tipos de uso final, vale ressaltar o elevado consumo dos sistemas de transporte vertical, que mesmo parado consome grande quantidade de energia, conforme observado por Batra et al. (2014). Foi constatado também que pela variação nas circunstancias de seu uso, como distância, quantidade de passageiros e sentido da viagem, sua demanda de energia também é bastante irregular.

Motores, bombas e compressores também representam importantes usos finais que deverão ser avaliados em cada caso.

\subsection{OBTENÇÃO DO CONSUMO DESAGREGADO}

A forma mais direta e, em um primeiro momento, mais simples de obter as informações do consumo desagregado é com a instalação de medidores de energia nos equipamentos de interesse. Suas medidas informam precisamente 0 consumo dos equipamentos monitorados, tornando fácil a avaliação dos sistemas envolvidos. Observa-se, no entanto, que nem sempre é possível obter tais 
informações de maneira trivial. Além do custo de instalar os medidores de energia e gerenciar suas informações, questões de acessibilidade e de identificação dos circuitos são barreiras que podem não ser de simples solução.

As instalações elétricas eram projetadas para minimizar seu custo inicial, reduzindo a quantidade de cabos e com quadros de distribuição que não previam um possível aumento de carga. Assim, diversos sistemas como o de iluminação, condicionamento ambiental e tomadas de uso geral compartilham o mesmo circuito elétrico partindo de um mesmo disjuntor, impossibilitando a medição individualizada de tais equipamentos. Quanto aos quadros de distribuição, é comum não haver espaço para inclusão de mais disjuntores, segmentando os circuitos, e nem para instalação de medidores de energia.

O ponto acessível para medição dos circuitos pode não ser o ideal, dependendo da quantidade de pessoas que passam no local. E seja por curiosidade, ou seja por acidente, o trânsito de pessoas nas proximidades do medidor pode causar riscos tanto aos transeuntes, quanto à instalação.

A quantidade de medições de interesse, também pode se tornar um impeditivo nesta forma de obtenção do consumo desagregado. O custo dos medidores pode não justificar sua implantação em todos os equipamentos. Principalmente nos casos onde a utilização deste equipamento não ocorra em local fixo, e gerenciamento de todas essas informações pode se tornar um custo muito elevado se comparado aos equipamentos monitorados e as economias possíveis em caso de eficientização de seu consumo.

Atualmente, muitas concessionárias, em parceria com universidades e centros de pesquisa, testam a utilização dos medidores inteligentes nas chamadas Redes Inteligentes de Energia. Elas consistem na utilização desses medidores, que possuem como principal característica a possibilidade de comunicação com outros dispositivos, sejam outros medidores, a central de operação da concessionária ou os equipamentos no interior da instalação.

Para este trabalho, sua grande contribuição é a possibilidade de obter os dados de consumo de energia em resoluções maiores que o comumente é disponibilizado 
pelos medidores da concessionária, permitindo ao gestor de energia realizar analises mais detalhadas e em tempo real.

Os dados de consumo de energia ao longo do tempo se dispostos em forma de gráfico formam a curva de carga da unidade consumidora, que mostra o consumo de energia em cada período do dia, geralmente de quinze em quinze minutos, e que é o utilizado pela concessionária de energia para o faturamento do consumidor. Nesta curva poderão ser observadas diversas características dos usuários como: consumo no período reservado, início das atividades, demanda máxima, entre outras.

No entanto, essa visão geral do consumo pode não ser suficiente, assim como o indicador de consumo por metro quadrado, pois ambos sofrem interferência de diversos fatores internos e externos que causam diferentes efeitos nos equipamentos. Portanto, torna-se necessário conhecer o consumo desagregado de uma instalação, que permite observar quanto que cada uso final representa na fatura de energia e qual o impacto dos diversos fatores em seu consumo.

Uma alternativa à instalação de medidores em todos os equipamentos é o levantamento das características elétricas dos equipamentos e dos hábitos de uso por parte dos usuários. Este método é chamado de Levantamento por Inspeção. Seus resultados, entretanto, podem ser muito imprecisos caso não se conheça bem os perfis de utilização dos equipamentos, assim como as peculiaridades de operação de tais equipamentos.

Buscando minimizar a necessidade dessa grande quantidade de medidores, muitas pesquisas são realizadas visando a identificação do consumo desagregado a partir da curva de carga obtida com a medição central de energia, como as análises de regressão linear utilizadas por (PRICE, 2010), (LAMMERS et. al., 2011) e (COUGHLIN et. al., 2009) que se mostram muito eficientes para identificar a relação do consumo de energia com a temperatura externa, monitorando portando os sistemas de aquecimento, ventilação e ar condicionado.

A figura 4 ilustra o conceito da aproximação feita por (LAMMERS et. al., 2011), que procura quantificar os efeitos no consumo de energia com o aumento da 
temperatura, amenizando o calor, e também com o abaixamento da mesma, na calefação do ambiente. Ele também identifica uma faixa neutra, onde o consumo se mantém praticamente constante.
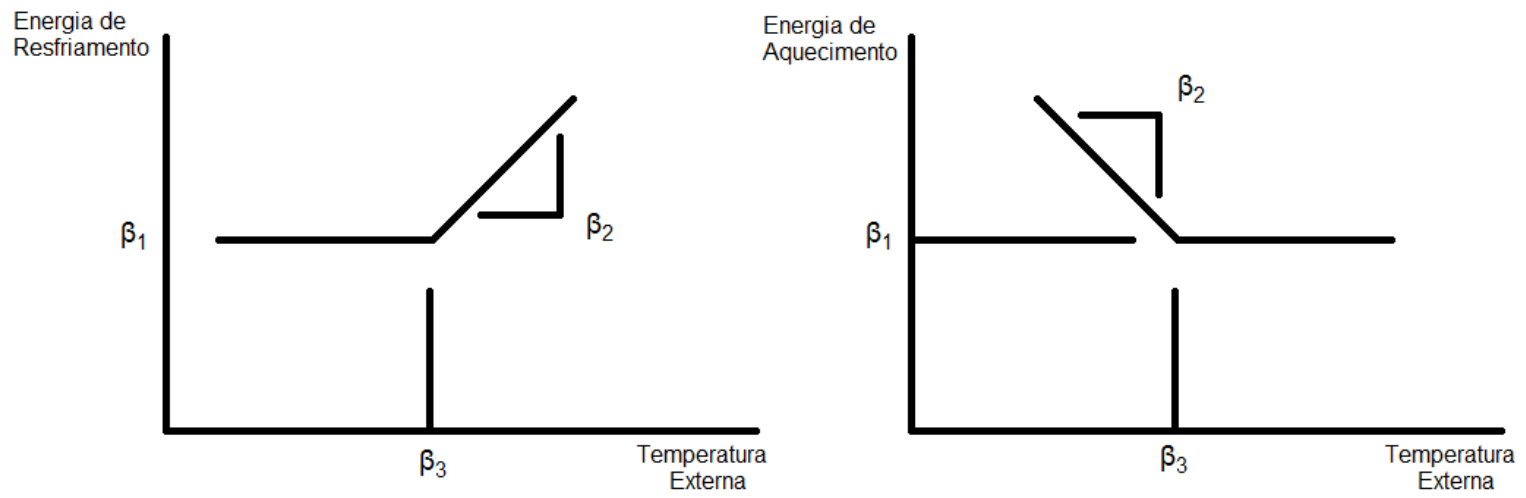

Figura 4 - Efeitos no consumo com a variação da temperatura externa.

(Fonte: adaptado de LAMMERS et al., 2011)

Outros estudos que também utilizam a medição central buscam identificar as assinaturas características da operação dos equipamentos são analisados por (ARMEL et. al. 2013) e (PARSON et. al., 2012) e dependendo da precisão desejada, envolve valores de consumo com taxa de amostragem na ordem de minutos, segundos, $\mathrm{kHz}$ e até $\mathrm{MHz}$, necessitando a instalação de um medidor, em paralelo ao da concessionária, mas que possua tal especificação. 


\section{MONITORAMENTO NÃO INTRUSIVO DE CARGA}

O Monitoramento Não Intrusivo de Carga, também conhecido pelo termo em inglês Non Intrusive Load Monitoring (NILM, sigla que será adotada neste trabalho), consiste na obtenção do consumo desagregado em usos finais de uma instalação através da medição de energia apenas no circuito principal.

Uma vez que cada equipamento elétrico possui seu próprio perfil de consumo de energia denominado de assinatura elétrica, os algoritmos desenvolvidos procuram identificar tais assinaturas na curva de carga da instalação, apontando assim os períodos de funcionamento dos equipamentos e seus respectivos consumos de energia.

Segundo constatação de Zeifman e Roth (2011), as metodologias de NILM são divididas basicamente em três etapas:

- Descrever matematicamente as características elétricas dos equipamentos, ou seja, suas assinaturas elétricas;

- Instalar medidores ou sensores com capacidade para obter os dados onde seja possível identificar tais assinaturas; e

- Detectar as assinaturas elétricas através de algoritmos matemáticos na curva de carga da instalação.

\subsection{ASSINATURAS ELÉTRICAS}

As assinaturas elétricas são as características de tensão, corrente e potência dos equipamentos quando estão em funcionamento. Tais características devem ser modeladas matematicamente $\mathrm{e}$ as particularidades de cada equipamento identificadas.

As características elétricas podem ser divididas em macroscópicas e microscópicas. As macroscópicas envolvem os valores de potências ativa e reativa, seja em regime ou durante a transição de estado, e são amostradas na 
ordem de minutos ou segundos. As microscópicas, por sua vez, utilizam valores das componentes harmônicas e relações entre formas de onda da tensão e da corrente dos equipamentos e possuem taxa de amostragem na ordem de $\mathrm{kHz}$ a $\mathrm{MHz}$ e são complementares às características macroscópicas na identificação dos equipamentos.

$\mathrm{Na}$ análise das assinaturas elétricas dos equipamentos foram identificadas quatro categorias que os distinguem:

i) De consumo permanente. Aqueles que ficam ligados o dia todo, todos os dias da semana, como um detector de fumaça.

ii) Do tipo Liga/Desliga. São os aparelhos que possuem demanda única ao serem utilizados. Lâmpadas e sanduicheiras elétricas são os exemplos encontrados nas residências.

iii) As máquinas de estados finitos. São aquelas que possuem estágios de operação bem definidos. A máquina de lavar roupas é um exemplo deste tipo de equipamento.

iv) De consumo continuamente variável. São os equipamentos de utilização aleatória, sem padrão definido de uso. Lâmpadas dimerizáveis e furadeiras são exemplos nesta categoria.

Principalmente na análise das características macroscópicas, os algoritmos utilizam a detecção de eventos, ou seja, uma variação significativa na curva de carga para identificar o equipamento. Nota-se, portanto, que os equipamentos da categoria (i), que estão sempre ligados sem variação na carga e os da (iv) que possuem variações contínuas na demanda são muito difíceis de discriminar pela curva de carga. Tais equipamentos, de maneira geral, ou possuem baixa demanda de energia, ou são pouco utilizados, contribuindo de maneira não muito significativa para o consumo total.

No caso das categorias (ii) e (iii), que representam a maioria dos equipamentos utilizados nas residências, a identificação é facilitada, pois é possível observar os degraus de demanda na curva de carga quando entram e saem de operação. 
Quanto maior a resolução dos dados, mais detalhes podem ser descritos pelas assinaturas dos equipamentos. Os dados de demanda de energia de um refrigerador registrados a cada segundo, por exemplo, mostram que ao iniciar seu ciclo de funcionamento apresenta um pico de demanda inicial, com redução gradual durante a operação e queda abrupta no final.

Com amostras da curva de carga de cinco refrigeradores, observáveis na figura 5, de modelos e potências distintas, Parson (2011) observou que tais características se repetiam, e o que diferenciava cada modelo era a potência de cada equipamento e a frequência e duração dos ciclos, ou seja, a partir de um modelo genérico deste tipo de equipamento é possível parametrizar tais características e identifica-las na curva de carga.

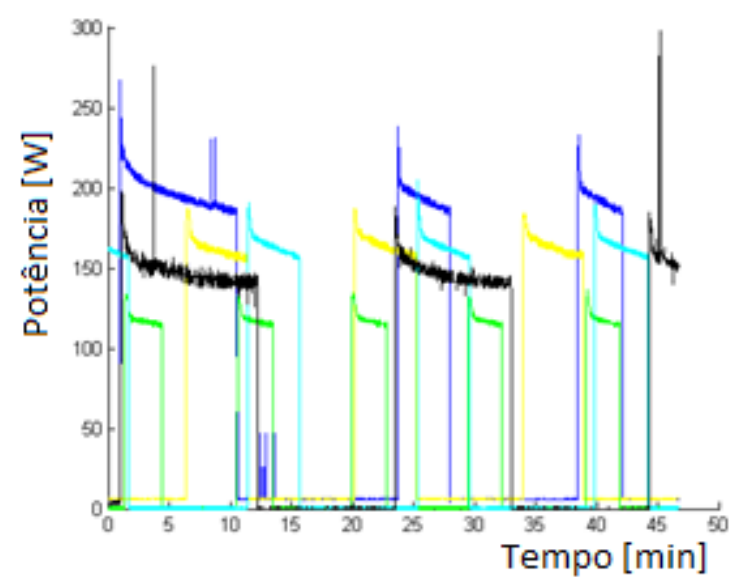

Figura 5 - Curva de carga de cinco geladeiras de modelos e potências distintos.

Fonte: Disaggregated Homes ${ }^{3}$

Em dados amostrados a cada sessenta segundos, o pico inicial de funcionamento do refrigerador não fica evidente, apesar de serem observáveis o início e final abruptos dos ciclos. Não havendo outros equipamentos de potência parecida, sua identificação na curva de carga ainda é possível, entretanto, com intervalo de um minuto entre as amostras das medições, aumenta a probabilidade de mais de um equipamento ser acionado durante esse período, dificultando a identificação de ambos. Com a resolução de uma medição a cada segundo, a ocorrência dessa

\footnotetext{
${ }^{3}$ Disaggregated Homes - Blog Oliver Parson - Disponível em: <http://blog.oliverparson.co.uk/ >, acesso em março, 2015.
} 
simultaneidade de eventos é mais rara, no entanto aumenta o volume de dados a ser analisado.

Além disso, a capacidade do hardware utilizado também deverá ser compatível com a escolha da assinatura elétrica, principalmente quando envolver as características microscópicas das assinaturas, como os harmônicos e as formas de onda de tensão e corrente, que elevam o volume de dados a serem transmitidos, armazenados e analisados necessitando de equipamentos específicos e de rápido processamento. Zeifman e Roth (2011) relatam a utilização de um pré-processamento local das informações, eliminando os períodos de medição considerados em regime, para transmissão, armazenamento e análise apenas dos dados com provável ocorrência de algum evento, ou seja, aqueles que apresentam variações significativas de energia, minimizando o tráfego de dados e os recursos de hardware necessários.

\subsubsection{Obtenção das Assinaturas}

As assinaturas dos equipamentos em uma instalação podem ser obtidas através da medição direta de seu consumo, ou pela medição do circuito principal com o acionamento controlado das cargas, passando por todos os ciclos de sua operação (BATRA et al., 2014). Apesar de fornecer maior precisão na identificação das assinaturas, pois utiliza como referência medições do próprio equipamento, esta metodologia é inicialmente intrusiva, o que pode ser inviável tecnicamente, ou indesejável por parte do usuário. Além disso, entrada de equipamentos desconhecidos poderá comprometer a identificação das demais cargas, ao tentar associar a nova assinatura a uma combinação das outras, já conhecidas. É necessário, portanto, mais uma medição isolada para cadastrar a nova assinatura, implicando nos problemas correlatos relatados anteriormente.

Outra possibilidade é identificar os tipos de assinaturas presentes na curva de carga real da instalação, agrupá-las de acordo com as semelhanças entre si e a periodicidade que ocorrem, para em seguida tentar associá-las a modelos matemáticos genéricos dos equipamentos e também aos hábitos de consumo dos usuários (HART, 1992). Esta técnica é menos precisa, pois sua referência 
depende do tipo de equipamento e de seu perfil de utilização na instalação, tornando a identificação de equipamentos pouco utilizados ou aqueles com diversos níveis de demanda mais complicada. No entanto, parece ser mais robusta quanto à identificação de equipamentos desconhecidos na instalação.

Nos estudos de caso que serão apresentados no capítulo seguinte, será utilizada a abordagem onde uma assinatura elétrica é identificada, para depois associá-la a um equipamento, procurando minimizar as interferências das medições no cotidiano da instalação.

\subsection{MEDIÇÃO DE ENERGIA}

Apesar de serem encontrados em todas as unidades consumidoras de energia, os medidores das concessionárias não possuem capacidade suficiente para fornecer dados que permitam a identificação do consumo desagregado em usos finais. Principalmente nas instalações residenciais, onde os medidores apenas acumulam o total de energia consumida pelos usuários, sem qualquer informação acerca da demanda máxima de energia ou consumo diário, é praticamente impossível obter o consumo individual de cada equipamento.

Para os grandes consumidores, os medidores utilizados podem apresentar os valores de demanda máxima e consumo total, tanto para o período de ponta, quanto para o fora de ponta, permitindo melhores análises, mas ainda insuficientes para avaliação do consumo desagregado. É possível também, solicitar os dados armazenados na memória de massa do medidor da concessionária, ou instalar um equipamento que, periodicamente, faça a leitura de tal medidor. Neste caso, é possível obter os dados de consumo com intervalos programáveis entre cinco e 60 minutos (ANEEL, 2011). Ainda assim, as avaliações do consumo desagregado só poderão ser realizadas acerca dos equipamentos fortemente influenciados pelas condições climáticas, ou por aqueles afetados pelo volume de produção em uma indústria, ou ainda aqueles com programação horária de funcionamento bem definida (ARMEL et al., 2013).

Portanto, é necessário instalar um medidor em paralelo ao da concessionária para obter as informações acerca do consumo de energia com a resolução desejada e 
que seja compatível com as assinaturas modeladas. Alternativamente, o medidor de energia poderá ser instalado de forma setorizada, fornecendo subsídios para gestão do consumo de energia de uma parte específica de uma unidade consumidora. Em casos onde a medição de energia é compartilhada, ou quando a instalação possui muitos equipamentos em operação, o monitoramento setorizado, permite obter melhores resultados no processo de desagregação do consumo.

No âmbito da implantação das Redes Inteligentes (Smart Grids), a instalação em massa dos Medidores Inteligentes (Smart Meters) pode ser uma grande incentivadora das pesquisas sobre de NILM, pois possui a capacidade de fornecer as informações de consumo e demanda de energia elétrica em intervalos programáveis com resolução de até uma medição por segundo ${ }^{4}$, o que é suficiente para identificar o consumo desagregado de muitos equipamentos em uma instalação, como em (HART, 1992).

Os Medidores Inteligentes possuem também a capacidade de comunicação com a concessionária e uma interface para interação com os usuários, o que permite que a gestão da energia seja realizada em tempo real. Informações sobre o preço da energia fornecida pela concessionária e o respectivo custo para o consumidor durante alguma atividade, pode alertar os usuários acerca dos impactos financeiros, e também ambientais, de seus hábitos de utilização da energia.

Pesquisas mostram que ao ser notificado sobre as despesas com a eletricidade referentes a cada atividade, o usuário sente-se estimulado a mudar seus hábitos visando reduzir seu consumo de energia (PARSON, 2014). Os resultados das medidas de economia de energia tendem a se diluir diante do consumo total de uma instalação. Ao fornecer tal informação de forma desagregada, nota-se que existe uma continuidade no estímulo pela redução de consumo, atingindo resultados mais duradouros e efetivos (ARMEL et al., 2013).

\footnotetext{
${ }^{4}$ Segundo especificações obtidas no site do fabricante IMS Soluções em Energia Ltda., disponível em: <http://www.ims.ind.br/catalogos/multimedidores/Default.html>.
} 


\subsection{IDENTIFICAÇÃO DO CONSUMO DESAGREGADO}

A detecção dos eventos na curva de carga e a identificação das assinaturas elétricas características dos equipamentos são grandes desafios computacionais desses algoritmos. O tipo de instalação analisada (residencial, comercial, industrial, pública, etc.), a quantidade e tipo de equipamentos utilizados, a quantidade de usuários que atuam na instalação acionando e desligando cargas, influenciam muito na precisão dos algoritmos.

Como já citado anteriormente, existem basicamente dois tipos de identificação do consumo desagregado. Um que procura por uma combinação de assinaturas elétricas dos equipamentos existentes que possua um consumo agregado semelhante ao que de fato é medido, logo é necessário o conhecimento prévio das cargas e suas respectivas assinaturas.

Quando não há referências prévias acerca das cargas monitoradas e suas respectivas assinaturas, procura-se identificar os eventos na curva de carga e associá-los em grupos de acordo com a semelhança em seus formatos, para em seguida, atribuir tal grupo de eventos a um tipo equipamento que possua uma assinatura elétrica compatível. Muitas vezes o pareamento entre assinatura e equipamento é realizado com base em modelos genéricos de cargas, ou por levantamento das características de tais equipamentos presentes na instalação.

\subsubsection{Detecção de eventos}

Segundo Batra et al. (2014), por serem aplicados na maioria dos casos em instalações residenciais, os algoritmos consideram as seguintes premissas para a identificação dos eventos:

- Há apenas um acionamento por vez, uma vez que a quantidade de equipamentos é reduzida e o intervalo entre as medições é na ordem de segundos;

- Após o acionamento das cargas seu consumo de energia permanece constante. São poucos os casos onde há um controle contínuo das cargas, ou que seu 
acionamento demore muito tempo até atingir uma estabilidade na demanda de energia;

- Há um padrão no comportamento de cada usuário em sua residência. Este fato pode auxiliar o software no aprendizado para identificação das cargas;

- Existência de cargas correlacionadas que geralmente são utilizadas em conjunto, como a televisão e o decodificador, por exemplo, o que pode facilitar na identificação desses equipamentos na curva de carga.

Assim, conforme a metodologia denominada "Janela com Margens" que foi desenvolvido por Azzini, Torquato e Silva (2014), ao utilizar uma janela de análise, que percorre toda a curva de carga, é possível identificar a ocorrência de um evento quando a diferença entre as demandas média final e inicial de tal janela superar um determinado valor, conforme pode ser observado na figura 6 .

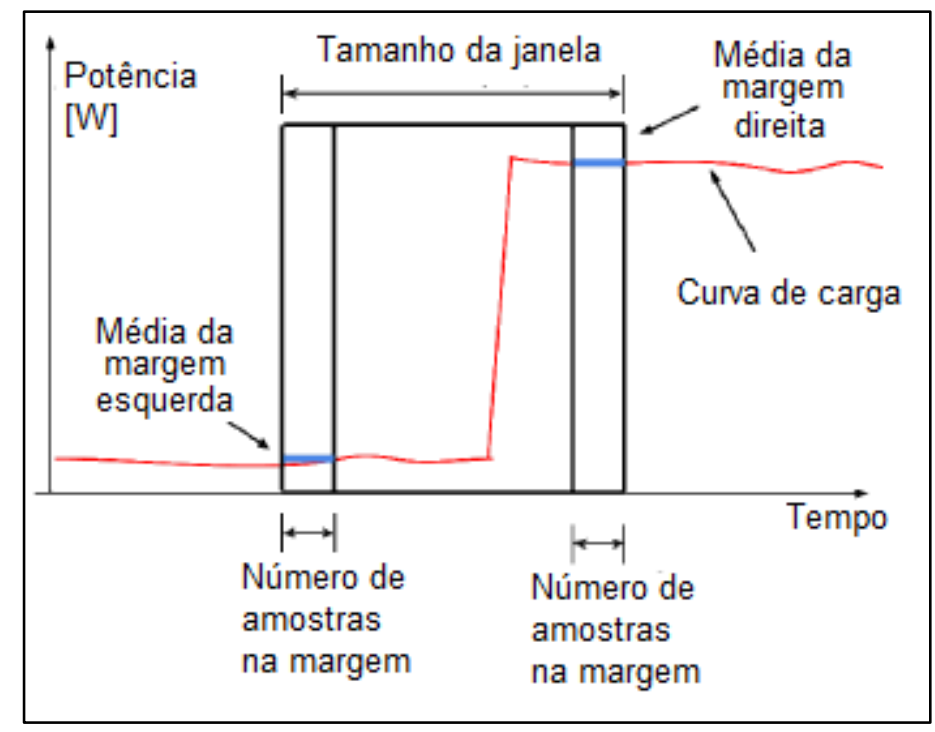

Figura 6 - Metodologia "Janela com Margens".

Fonte: adaptado de (AZZINI; TORQUATO; SILVA, 2014).

Cabe observar que o tamanho da janela deverá ser suficientemente pequeno para evitar que mais de um evento possa ocorrer neste intervalo, porém deverá ter tamanho suficiente para acomodar além do período de transição do evento, as duas margens para o cálculo da magnitude do evento. 
O número de amostras nas margens deverá ser suficiente para minimizar os efeitos das eventuais flutuações de demanda tanto anteriores, quanto posteriores ao evento, e estão limitadas à metade do tamanho da janela de análise.

Quanto ao limiar de detecção de evento é necessário avaliar os equipamentos utilizados na instalação e suas respectivas potências nominais. Valores muito baixos permitem identificar as operações com as cargas menores, porém aumenta a probabilidade de identificar um ruído como um evento real, os chamados falsos positivos. Aumentar o valor do limiar, no entanto, despreza os eventos de cargas cujas potências nominais são menores que tal limiar.

Azzini, Torquato e Silva (2014) apresentam neste mesmo trabalho outra possibilidade de identificar um evento. Computacionalmente mais simples, a metodologia "Amostra Deslocada", é baseada no valor da derivada da curva de carga que, neste caso, corresponde à diferença entre duas amostras consecutivas, conforme ilustrado na figura 7 .

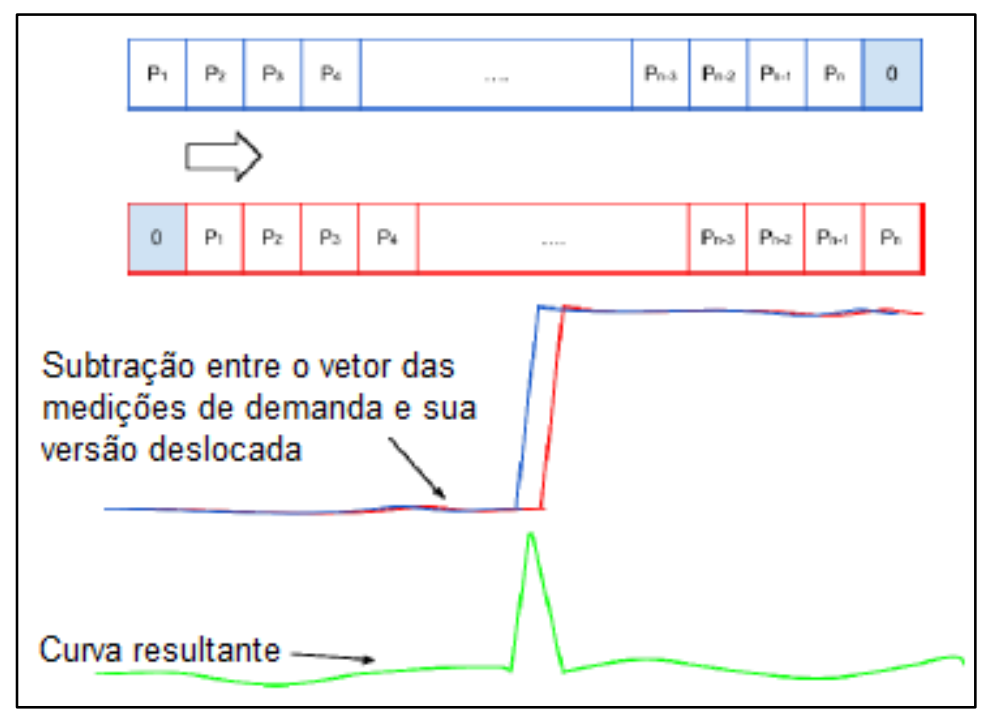

Figura 7 - Exemplo da metodologia "Amostra Deslocada"

Fonte: adaptado de (AZZINI; TORQUATO; SILVA, 2014)

Quando o valor da diferença entre a curva original e a deslocada ultrapassa um determinado limiar, registra-se, neste ponto, a possibilidade de ocorrência de um evento. Em seguida, calcula-se a diferença entre as demandas médias de uma janela imediatamente posterior e outra imediatamente anterior ao possível evento, 
e se a diferença for mantida acima do limiar estipulado, confirma-se o evento. Tal verificação é necessária para minimizar a ocorrência de falsos positivos, uma vez que esta abordagem é muito sensível a flutuações e picos de demanda. Assim como na "Janela com Margens", o valor do limiar de detecção e o tamanho da janela de confirmação devem ser analisados para cada tipo de instalação e de equipamentos utilizados.

Verifica-se em Azzini, Torquato e Silva (2014) que ajustes nos parâmetros da metodologia "Janela com Margens" elevaram o índice de acerto de 60\% para 80\%. $\mathrm{Na}$ "Amostra Deslocada", após os ajustes, os índices de acerto atingiram taxas maiores que $75 \%$.

Tais metodologias se mostraram eficientes na identificação dos eventos em uma instalação residencial, entretanto, visando estender sua aplicação em instalações mais complexas, como os prédios comerciais, foi realizada uma combinação das metodologias com algumas adaptações em relação aos tamanhos das janelas de detecção, que foram flexibilizados conforme o comportamento da curva de carga, permitindo um aumento da janela de avaliação em casos onde a variação na demanda mantenha valores elevados, positivos ou negativos, por longos períodos.

Segundo Batra et al. (2014), ao contrário do que ocorre nas instalações residenciais onde a maioria das cargas opera em um regime constante, nos grandes edifícios comerciais ou industriais, é mais provável que haja equipamentos com controle contínuo de carga durante sua operação e também equipamentos que possuem tempo de partida na ordem de dezenas de segundos, até que se atinja uma demanda de regime. Ainda segundo os autores, a quantidade de equipamentos também é encarada como empecilho ao analisar as instalações comerciais, pois aumenta a probabilidade das cargas serem acionadas simultaneamente, o que irá dificultar sua identificação.

Diante deste fato, a flexibilização da janela de avaliação procura priorizar uma avaliação mais precisa dos equipamentos demandam mais energia e operam de maneira mais complexa, em detrimento das variações de outras cargas menores. 
Por outro lado, Batra et al. (2014) ressaltam que é mais provável também que exista uma equipe especializada, que realize um acompanhamento desses sistemas de maior consumo, como no caso dos sistemas de AVAC, e que podem fornecer subsídios, como a programação horária de funcionamento, para a identificação de tais equipamentos na curva de carga da instalação. A diferenciação entre dias úteis e finais de semana também é considerada como vantagem das instalações comerciais em relação às residenciais, pois separam dois comportamentos distintos de uso dos equipamentos na mesma instalação.

Tal avaliação permite identificar o consumo de energia que é independente das atividades desenvolvidas na instalação, geralmente representada pela curva de carga de um domingo, o que se torna mais um item de avaliação para a gestão de energia.

\subsubsection{Agrupamento dos eventos}

Uma vez que os eventos foram identificados, deve-se associá-los aos equipamentos que os produziram. Entretanto, a priori, tais assinaturas não são conhecidas o que complica realizar tal correspondência.

Portanto, inicialmente os eventos devem ser agrupados com outros que exibam as mesmas características, como valor da demanda, presença de picos de operação, demanda reativa, quando houver, formato da curva, entre outras que possam diferenciá-los.

$\mathrm{Na}$ ausência de equipamentos com características semelhantes, tais grupos tendem a ficar visivelmente discriminados, como ilustrado pela figura 8 , onde foram utilizados os valores de potências ativa e reativa, para indicar as prováveis regiões que os eventos de cada tipo de equipamento ocupam.

Os eventos de mesma magnitude, porém de sinal contrário poderão ser associados a um mesmo equipamento, fornecendo seus respectivos períodos de funcionamento. No entanto, os eventos de potência ativa negativa, que correspondem ao desligamento das cargas, podem divergir em magnitude dos eventos positivos, pois as características elétricas de muitos equipamentos se alteram durante o funcionamento atingindo uma diferença de até $10 \%$ do valor de 
demanda inicial. Neste caso, a frequência desses eventos poderá ser utilizada para associá-los a um equipamento em comum, permitindo que se calcule seu período de funcionamento.

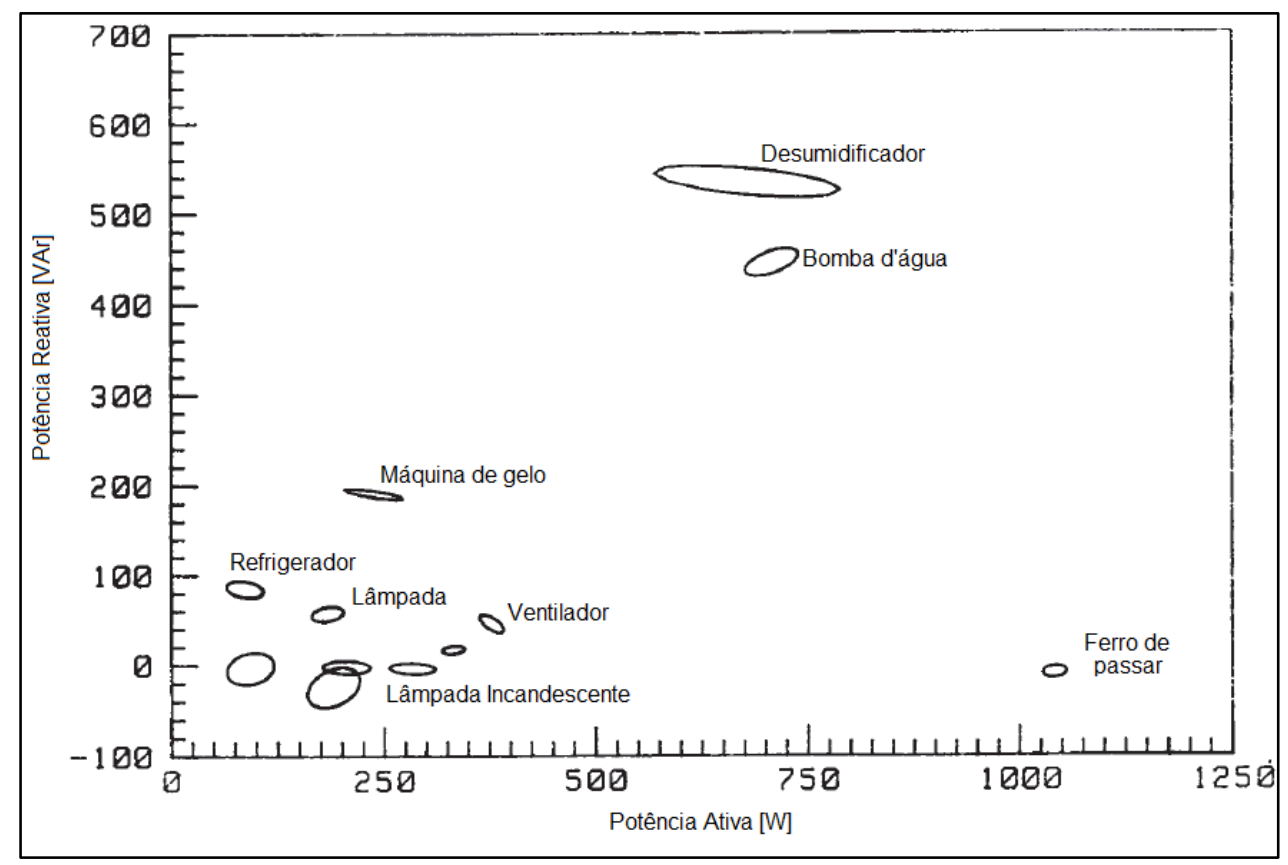

Figura 8 - Região de agrupamento dos eventos.

Fonte: Adaptado de (HART, 1992).

\subsubsection{Identificação das Assinaturas Elétricas}

Ao discriminar as assinaturas elétricas e agrupá-las entre as correspondências dos eventos positivos e negativos, é possível associar tais assinaturas a um equipamento específico. O conhecimento das características das cargas existentes na instalação e seu respectivo comportamento durante a operação facilita a conexão entre assinatura e equipamento.

Para equipamentos de grande consumo de energia é improvável que existam outros com as mesmas características e que não sejam para mesma função. É comum encontrar dois ou três chillers de mesma potência em uma instalação. Neste caso é indiferente do ponto de vista do consumo desagregado identificar os eventos de um ou outro equipamento, pois ambos contribuem para o mesmo uso final. Entretanto, ao analisar as potências ativa e reativa, tempo de operação e frequência de acionamento é muito provável as características sejam distintas 
quando o uso final não é o mesmo, permitindo uma correta associação entre equipamentos e assinaturas.

Para as demais assinaturas é necessário realizar um cadastro dos equipamentos existentes e suas respectivas potências nominais. Uma estimativa de períodos de utilização poderá auxiliar os algoritmos na associação entre assinaturas e equipamentos. Alternativamente, modelos genéricos dos equipamentos poderão fornecer as informações necessárias para identificação das assinaturas, como no caso da curva de potência característica dos refrigeradores, observadas por Parson (2011) e ilustrada pela figura 6, apresentada anteriormente.

\subsection{BANCOS DE DADOS PUBLICAMENTE DISPONIBILIZADOS}

$\mathrm{Na}$ tentativa de aproximar as pesquisas, muitos pesquisadores realizaram medições de energia em diversas instalações de maneira detalhada e as disponibilizaram publicamente. Tais medições contemplam os dados agregados de toda a instalação, assim como os dados segmentados por circuitos, que muitas vezes fornecem os consumos desagregados dos aparelhos.

\subsubsection{Reference Energy Disaggregation Dataset}

Disponibilizado por Kolter e Johnson (2011), o Reference Energy Disaggregation Dataset (REDD) é um banco de dados especificamente desenvolvido para alavancar as pesquisas sobre consumo desagregado. Os autores notaram que, comparados com outras áreas de pesquisa, como na Biologia Computacional e na Visão por Computador ${ }^{5}$, o consumo de energia não possui muitas informações disponíveis publicamente aos pesquisadores. Assim, cada pesquisador utiliza seu próprio banco de dados e suas próprias metodologias de avaliação dos resultados obtidos, impossibilitando a comparação entre os métodos.

\footnotetext{
${ }^{5}$ Tanto na Biologia Computacional quanto na Visão por Computador a ideia é extrair as informações a partir de reconhecimento de padrões, seja em uma sequência genética ou em uma imagem.
} 
O REDD possui medições do consumo de energia de algumas residências e foi disponibilizado publicamente das seguintes formas:

i) Valor do total de corrente nas duas fases e de tensão em uma, com resolução de $15 \mathrm{kHz}$, para avaliações quanto aos harmônicos e às formas de onda;

ii) Valor da demanda total de energia de cada fase, com resolução aproximada de uma medição por segundo;

iii) Valor da demanda de cada circuito parcial da residência a cada três ou quatro segundos. Os circuitos alimentam, na maioria dos casos, apenas um equipamento, provendo seu consumo desagregado diretamente. Quando havia mais de um, eles foram agrupados pelo tipo, como no caso dos equipamentos eletrônicos e de iluminação.

\subsubsection{Commercial Building Energy Data Set}

O Commercial Building Energy Dataset (COMBED) apresenta as medições realizadas no Indraprastha Institute of Information Technology - Delhi (IIITD), com valores de toda instalação, assim como os segmentados entre os setores do Instituto, com resolução de 30 segundos entre cada medição. Há informações do bloco residencial, auditório, biblioteca, setor acadêmico, entre outros. No setor acadêmico há ainda uma segmentação por serviços, como iluminação, elevadores e de condicionamento ambiental, assim como a divisão por andar (térreo e mais quatro pisos).

A maioria das pesquisas referentes ao NILM é realizada em instalações residenciais, por diversas razões, já citadas anteriormente. Por outro lado, o consumo energético em uma instalação comercial ou industrial é muito maior que nas residenciais, o que pode indicar um maior potencial de economia de energia pela identificação de seu consumo desagregado.

Segundo (BATRA et al., 2014) a implantação em instalações comerciais poderá ser mais bem aceita, pois pelo fato de ser mais complexa que a residencial, é mais provável que haja uma equipe especializada para gerenciar tal insumo. Os 
sistemas automatizados que possam existir nessas instalações também podem fornecer dados relevantes que auxiliam no processo de desagregação do consumo de energia. Os autores ressaltam que apesar da grande variedade de instalações comerciais, muitas podem ser consideradas similares aos escritórios de Tecnologia da Informação - TI, onde as cargas predominantes são o sistema de AVAC e dos equipamentos de TI.

\subsubsection{Outros bancos de dados disponibilizados}

Outros bancos de dados relatados por Batra et al. (2014), que favorecem o desenvolvimento das pesquisas são o BLUED, no caso de instalações residenciais e também o BERDS, no caso das instalações comerciais.

O Building-Level fUlly-labeled dataset for Electricity Disaggregation (BLUED) monitorou por uma semana os dados de tensão e corrente em uma residência nos EUA, a uma frequência de $12 \mathrm{kHz}$ e os instantes de cada evento para cada equipamento foram registrados, para posterior análise dos dados. Anderson et al. (2012) destacam que assim como nos grupos de pesquisa de detecção facial e de reconhecimento de voz, a disponibilização dos bancos de dados permitem que comparações entre os algoritmos possam ser realizados sob uma base comum de informações, intensificando os estudos de cada área.

O BERkeley EneRgy Disaggregation Data Set (BERDS) fornece as informações do Cory Hall na Universidade da Califórnia, com dados registrados a cada 15 minutos e informações segmentadas por iluminação, bomba de água quente, sistema de AVAC e tomadas de uso geral. 


\section{ESTUDO DE CASO}

A partir das metodologias de NILM desenvolvidas por diversos autores, foram escolhidos parâmetros que pudessem ser aplicados na avaliação do consumo de energia do prédio da Engenharia Elétrica da Escola Politécnica da Universidade de São Paulo (EE-EPUSP), no qual foram realizadas medições de potência ativa e reativa, integralizadas a cada cinco segundos.

Inicialmente os algoritmos foram analisados utilizando bancos de dados disponíveis publicamente e que apresentam tanto os dados agregados de toda a instalação, quanto às medições do consumo desagregado dos equipamentos, ou ao menos por serviço energético.

A partir dos bancos de dados disponíveis publicamente foram avaliadas as técnicas de obtenção do consumo desagregado, levando em consideração os tipos de dados disponíveis para o estudo de caso. Logo, para este trabalho especificamente, foram analisadas apenas as características macroscópicas dos equipamentos, buscando na curva de carga as informações de transição de estados e a operação em regime.

Inicialmente foram utilizados os dados residenciais do REDD, pois possui medições a cada segundo e foram analisados também os dados do COMBED, pois, apesar de apresentar os dados a cada 30 segundos, trata-se de uma instituição de ensino, assim como a EE-EPUSP, onde algumas semelhanças poderão ser encontradas, permitindo melhores análises.

\subsection{REDD}

Os dados do REDD foram utilizados para avaliar a metodologia desenvolvida neste trabalho, que foi baseada em uma combinação das metodologias "Janela com Margens" e "Amostra Deslocada" desenvolvidas por Azzini, Torquato e Silva (2014), mas que foi adaptado para suportar os diferentes perfis de equipamentos existentes não apenas nas residências, mas também em outros tipos de instalação. 
A adaptação desenvolvida consiste na flexibilização do tamanho da janela avaliação utilizada para detectar um evento e programada da seguinte maneira:

- Uma janela fixa de três amostras da medição que percorre toda a curva de carga é avaliada quanto à dispersão entre seus valores;

- Ao detectar variação de potência maior que um determinado limiar, determina-se o instante de início da janela de análise;

- Enquanto a dispersão nas amostras da janela fixa se mantem acima do limiar mínimo, a janela de análise se expande para englobar todo o evento;

- Quando a dispersão entre as amostras da janela fixa fica abaixo do limiar, determina-se o instante final da janela de análise;

- Os parâmetros da metodologia "Janela com Margens" são determinados a partir do tamanho da janela de análise obtida e a magnitude do evento é calculada através da diferença entre a média da margem final e a média da margem inicial, tal qual na metodologia original;

- A duração do evento é associada ao evento; e

- Os valores da análise da "Amostra Deslocada" são associados ao evento de duas formas. Como a soma dos módulos, que avalia a presença de picos de energia e o valor máximo entre os módulos, que avalia se a carga variou gradualmente, ou se atingiu o valor de forma instantânea.

Assim são determinados os parâmetros deste evento e uma nova janela de análise poderá ser parametrizada.

Quanto ao banco de dados utilizado, o REDD é um conjunto de medições de consumo de energia residencial, que por questões de privacidade e segurança, foi indicado apenas que se localiza na região da grande Boston, no estado de Massachusetts, nos Estados Unidos da América. Das medições disponíveis, foram utilizados os dados da instalação identificada como "Residência 3", onde existem diversos equipamentos como refrigerador, lava-louças, forno elétrico, lavadora e secadora de roupas, forno micro-ondas, entre outros, que foram monitorados individualmente, além dos circuitos de lâmpadas e tomadas de uso geral, onde 
não é possível especificar um único equipamento sendo utilizado em tais pontos de medição.

Analisando os resultados obtidos para o dia 18 de abril de 2011 na avaliação dos dados do REDD, é apresentada na figura 9, a curva de carga da residência, onde é possível observar o perfil de consumo dos usuários nesta instalação, e na figura 10, podem-se observar diversos grupos de carga identificados e seus pareamentos entre eventos positivo e negativo.

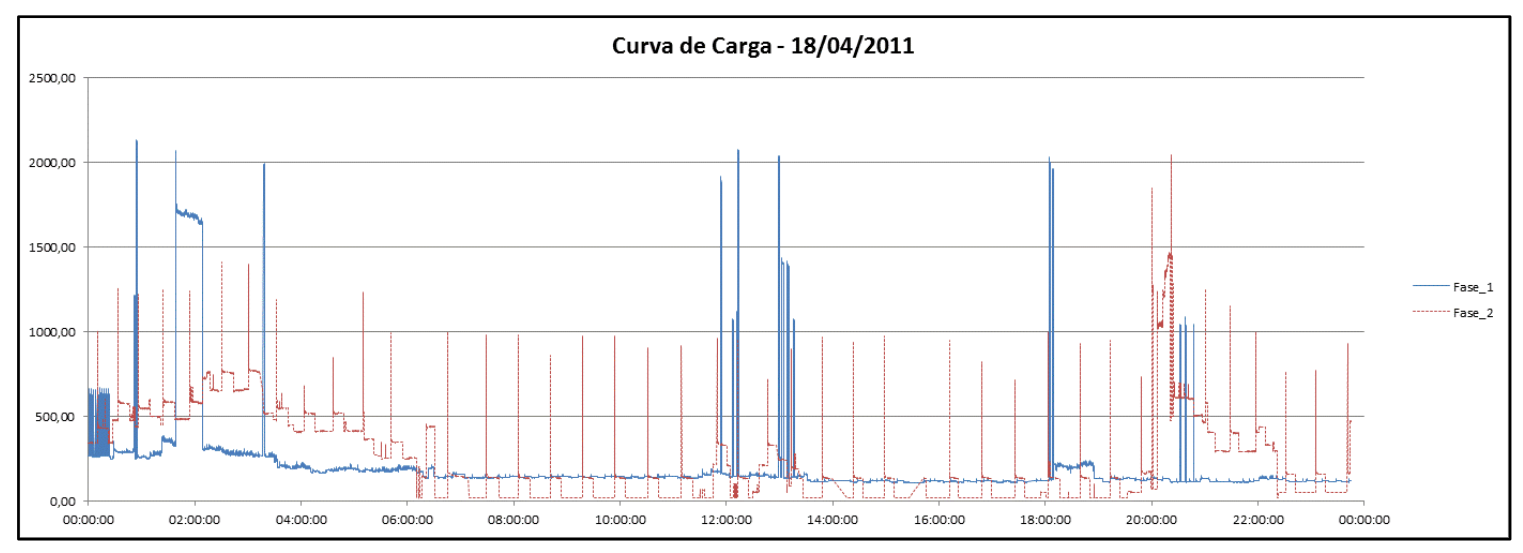

Figura 9 - Curva de carga residencial

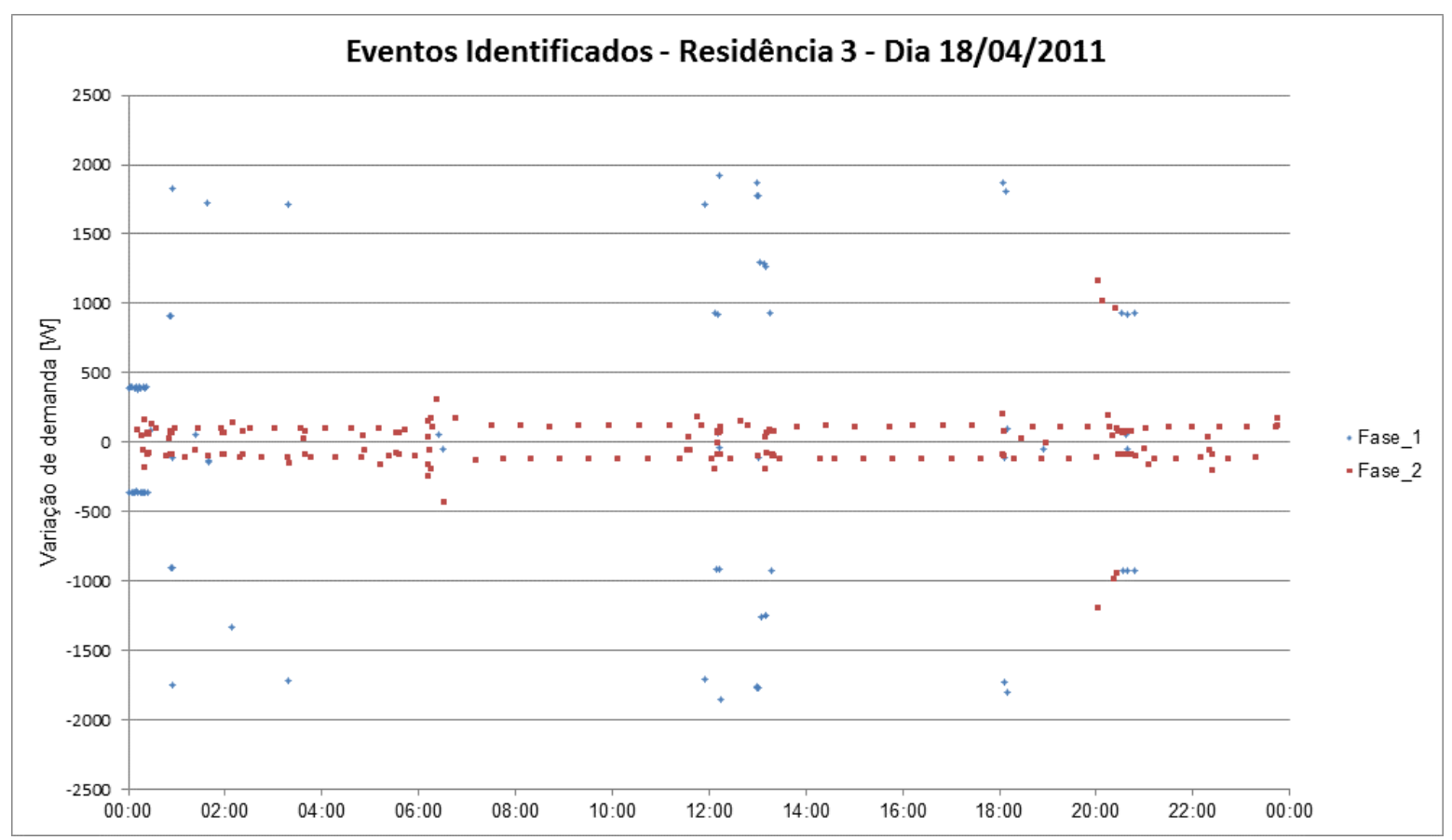

Figura 10 - Identificação dos eventos no dia 18 de abril de 2011. 
Pelos gráficos 9 e 10, é possível observar que os períodos de maior consumo de energia elétrica nesta residência são no período da madrugada, da meia-noite às 6:00h, durante o horário de almoço, entre 11:00h e 13:00h, e ao anoitecer, após as $18: 00 \mathrm{~h}$.

Nos horários de almoço e jantar, os equipamentos utilizados são relacionados à cocção e aquecimento dos alimentos. Para as atividades que envolvam o consumo imediato dos seus produtos, como no preparo das refeições, no entretenimento e iluminação, o consumo de energia se dá no instante que o usuário necessita do serviço energético.

No entanto, durante a madrugada, horário no qual a energia é mais barata, podem ser acionados os equipamentos relacionados á lavação de roupas e louças. Tais equipamentos não precisam ser operados na presença dos usuários, uma vez que podem ser programados para funcionamento no horário de energia mais barata, ou para um período de menor consumo na instalação, ou seja, sem sobrecarregar os circuitos de alimentação da residência.

Já na figura 11, é possível identificar outro agrupamento de carga, desta vez com um elemento que atua em ambas as fases da residência, o que representa mais uma característica que poderá ser utilizada para discriminar os equipamentos que possuem tal perfil de consumo.

A identificação de um evento, sabidamente bifásico, em apenas uma das fases pode significar que equipamentos monofásicos atuaram no mesmo instante na outra fase, gerando um evento desconhecido e que ficará sem o respectivo par, de magnitude semelhante, porém com o sinal invertido. Neste caso, a falta de pareamento de eventos ocorridos entre as fases, permite inferir que na fase onde foi identificado o sinal desconhecido, o evento do equipamento bifásico componha tal sinal e a diferença pertença ao equipamento monofásico.

A ocorrência de eventos simultâneos também pode ocorrer entre dois ou mais equipamentos monofásicos, gerando um sinal desconhecido, desta vez, sem a referência da outra fase para indicar um possível equipamento que tenha operado em tal instante. Neste caso, as análises seguem até que sejam identificados os 
eventos individuais conhecidos, cujos respectivos pares, até então não identificados na curva de carga, formem um sinal semelhante ao evento desconhecido.

Cabe observar a presença de um equipamento que liga e desliga periodicamente, em ambos os dias. Característica típica de um refrigerador, que pode ser associado a tal assinatura na curva de carga.

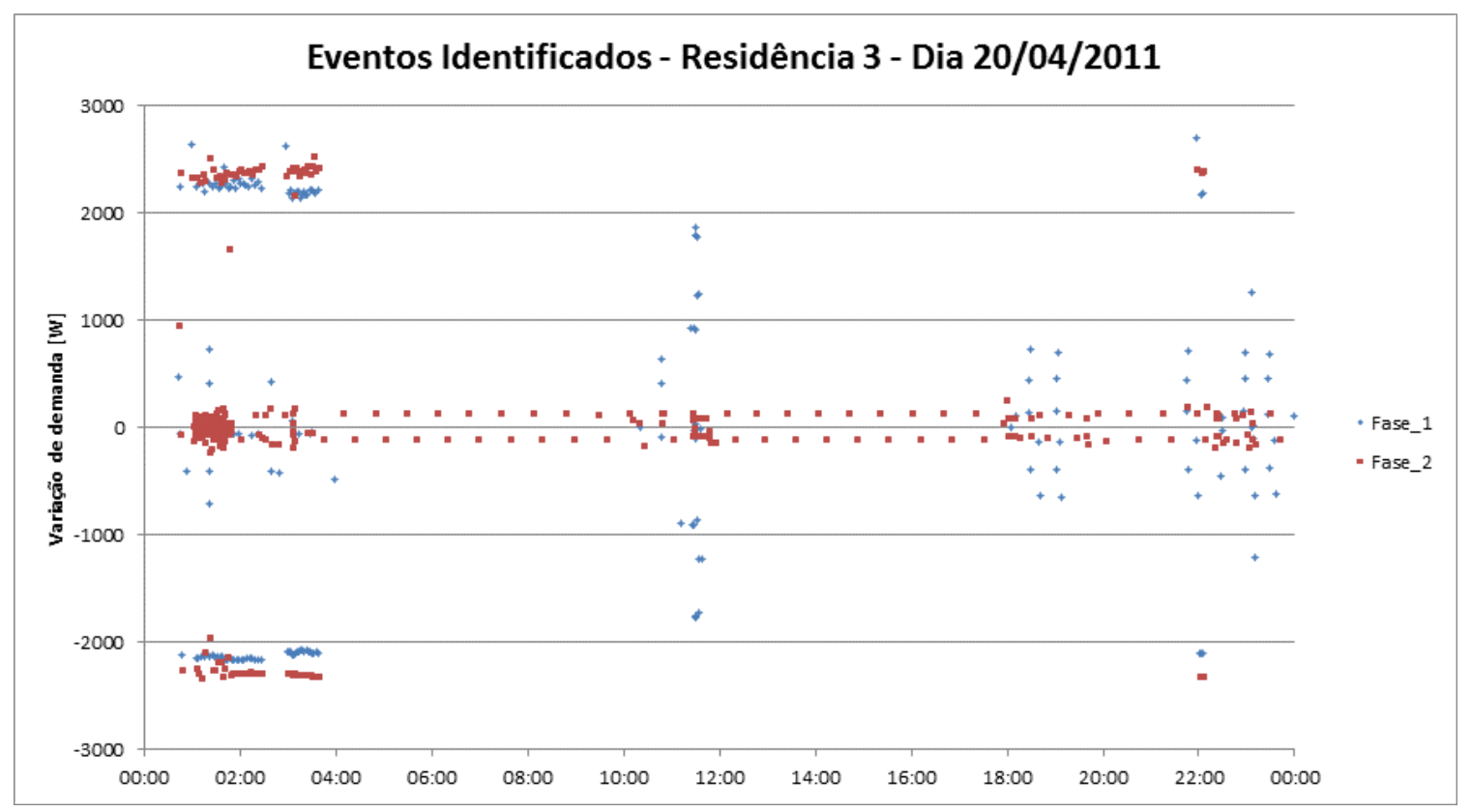

Figura 11 - Eventos identificados no dia 20 de abril de 2011.

Existe uma região no gráfico da figura 12, entre 1:00h e 2:00h onde não é possível identificar uma assinatura clara dos eventos, fato que ocorreu também no dia 21 de abril, porém no período noturno, ente 19:00h e 20:00h. 


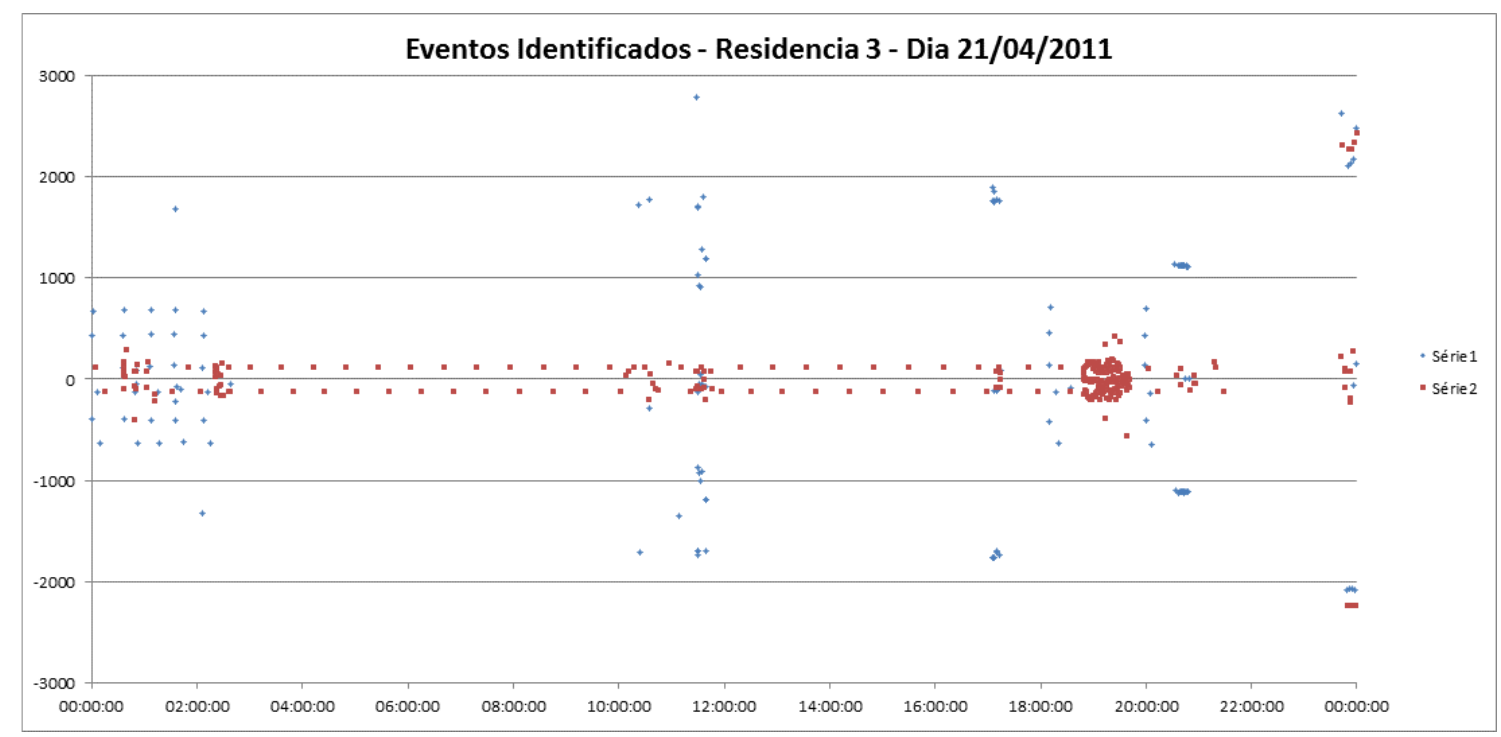

Figura 12 - Eventos identificados no dia 21 de abril de 2011.

Apesar de não identificar um equipamento específico, é possível detectar a ocorrência de diversos eventos em um curto período e na mesma fase da instalação, o que aumenta a probabilidade de se tratar um mesmo equipamento, ou um conjunto deles.

Para verificar com mais detalhes as observações feitas anteriormente, a curva do dia 20 de abril desta residência será exibida em intervalos menores, onde as peculiaridades do perfil de consumo poderão ser mais bem exploradas e as ocorrências de eventos simultâneos identificadas.

No período inicial deste dia, apresentado na figura 13 a seguir, é possível observar um perfil de carga que se repete simultaneamente nas duas fases da residência, indicando a possível operação de um equipamento bifásico. 


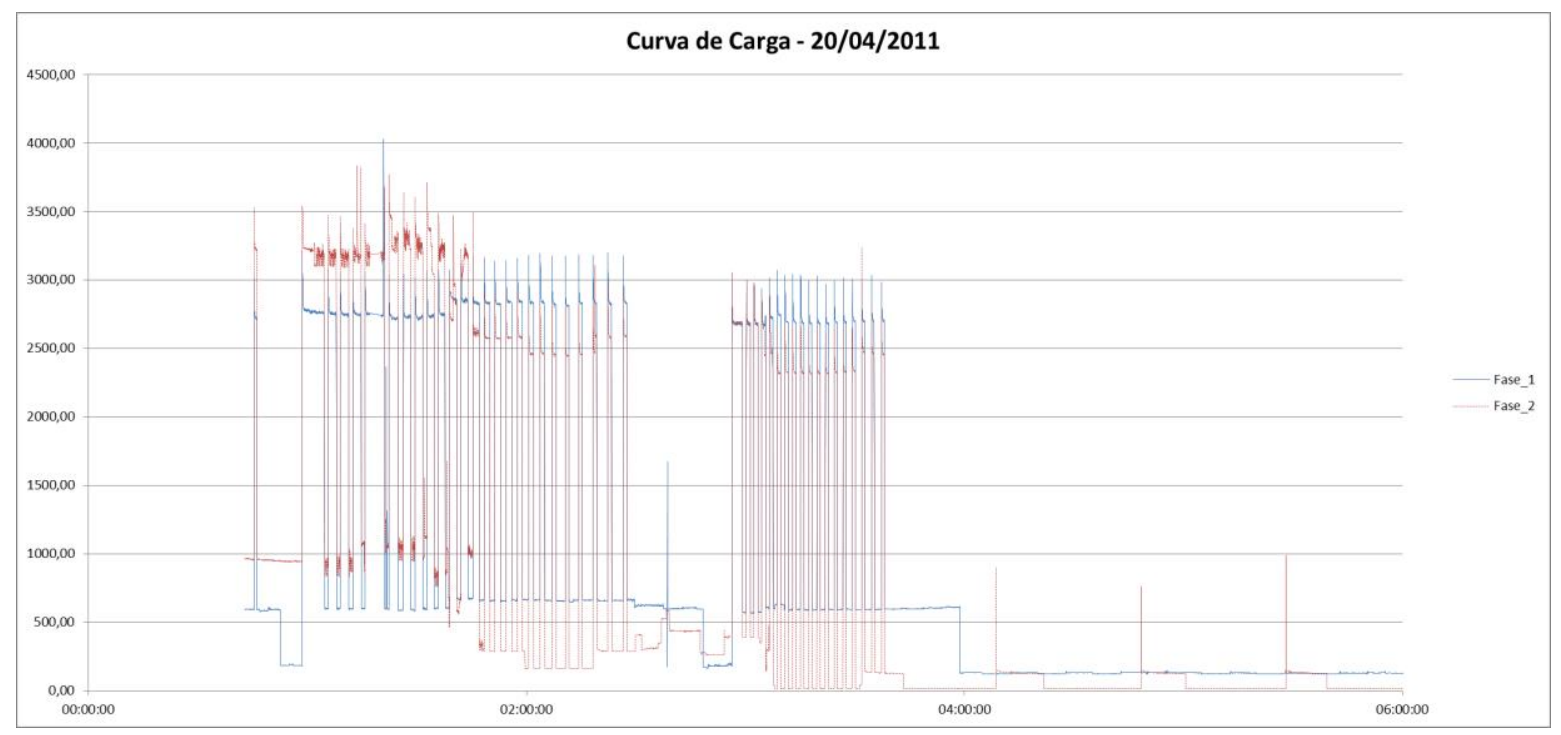

Figura 13 - Período inicial da curva de carga do dia 20/04/2011.

Na figura 14 a seguir é possível verificar os eventos identificados para o período inicial do dia 20 de abril. Em muitos casos fica evidente o pareamento dos eventos positivo e negativo, correspondentes aos atos de ligar e desligar um equipamento, respectivamente.

Em outros, tal pareamento não é claro à primeira vista. Quando dois ou mais eventos ocorrem no mesmo instante, seus efeitos na curva de carga se somam, respeitando o sinal do evento, e uma "nova" assinatura é identificada. Eventos com o padrão já reconhecido, sem o respectivo perfil oposto identificado na curva de carga, podem ser a causa do "novo" evento. Caso os efeitos inversos dos eventos não pareados sejam compatíveis com o "novo" evento, tanto em magnitude, quanto na sequência dos fatos, ou seja, o efeito de ligar um equipamento ocorre antes do efeito de desligá-lo, o "novo" evento pode ser considerado como uma combinação dos dois eventos complementares aos eventos sem par. 


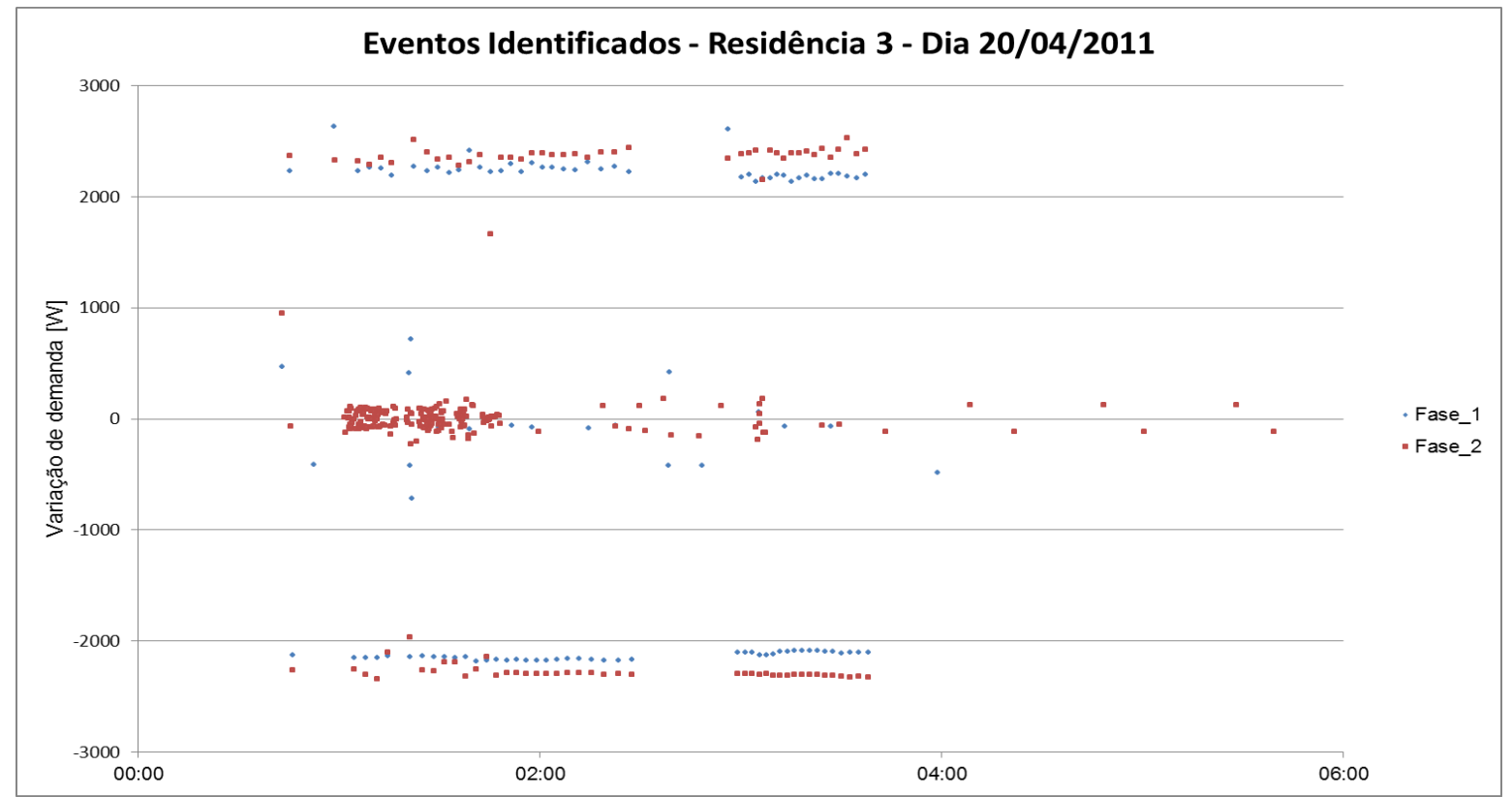

Figura 14 - Eventos identificados na curva de carga no período da madrugada.

É possível verificar também, uma sequência de eventos, em ciclos que se repetem com variações na duração, mas de potências iguais. Tais eventos podem ser mais bem observados nas figuras 15 e 16 a seguir, onde uma sequência de três patamares de demanda ocorrem diversas vezes e sempre na mesma ordem, com variação no intervalo entre os eventos.

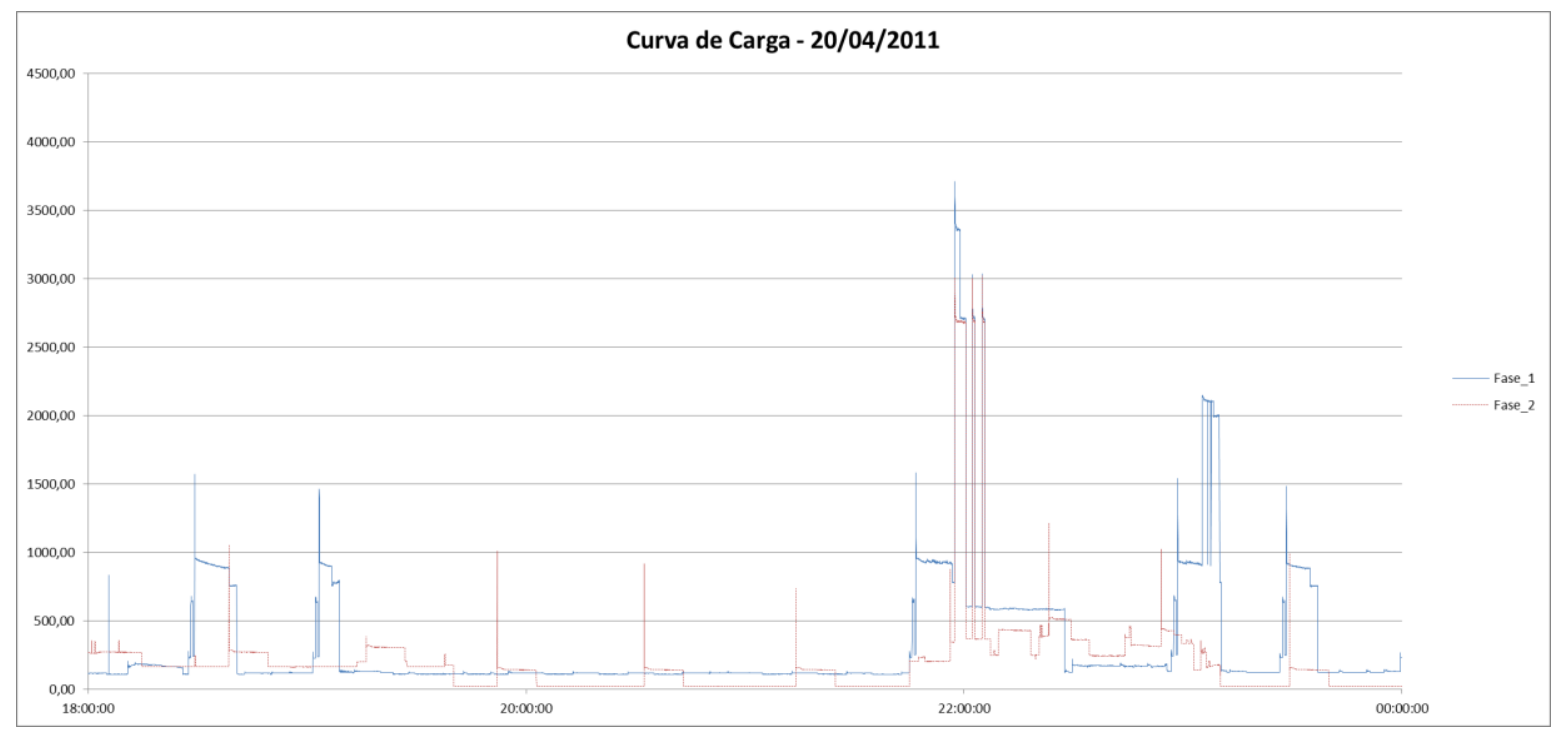

Figura 15 - Curva de carga do dia 20 de abril de 2011 


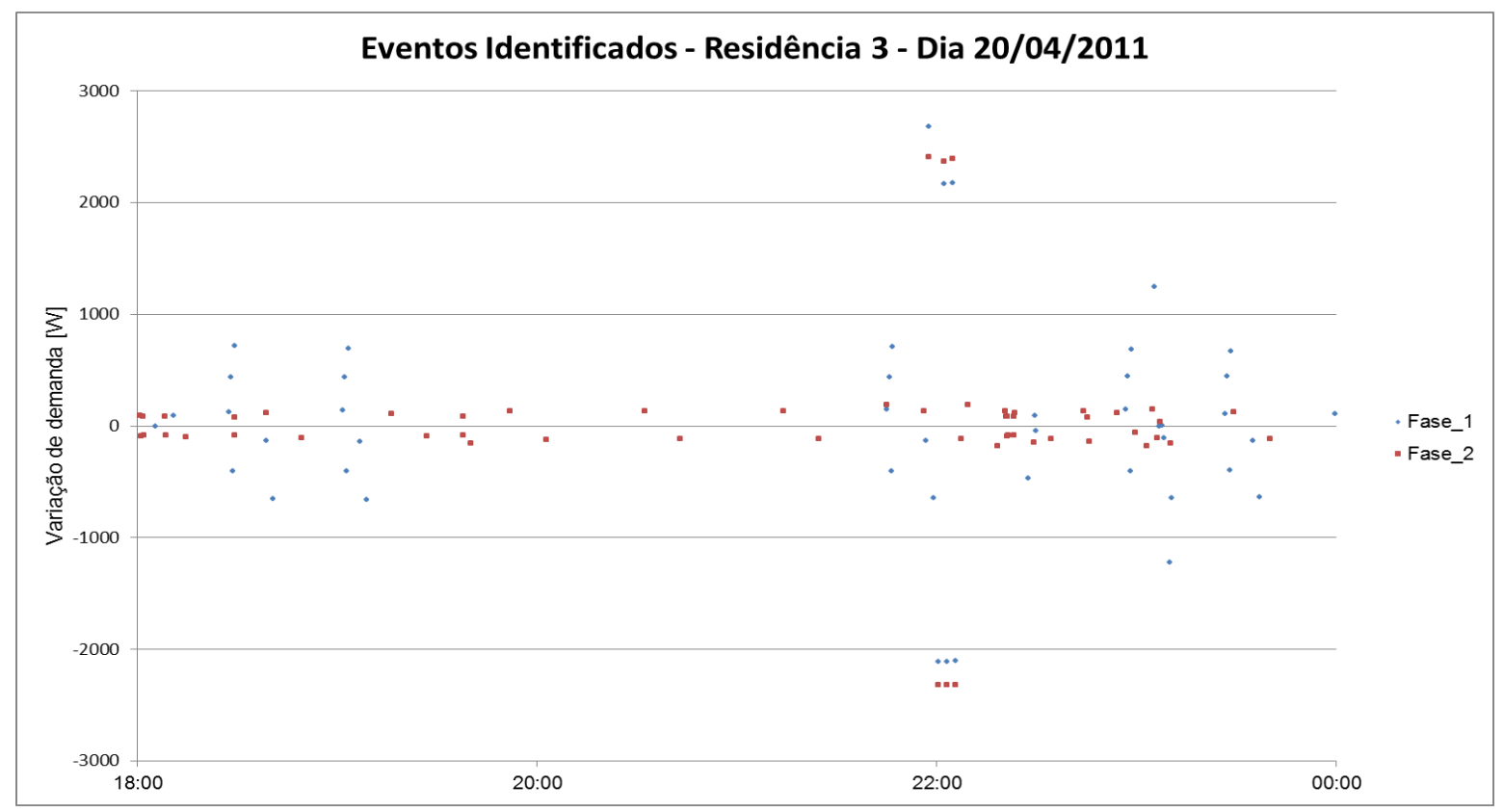

Figura 16 - Eventos identificados no período noturno.

Outro padrão detectado, ao menos para esses três dias, é a repetição dos eventos ocorridos próximos ao meio-dia, que podem indicar que seja algum equipamento relacionado à cocção de algum alimento.

Após a identificação dos eventos, deve-se classifica-los quanto à magnitude, tempo de transição, sequência dos eventos, entre outras características que possam diferencia-los, para assim serem atribuídos aos respectivos equipamentos que ocasionaram tais perturbações na curva de carga.

Nas figuras 17 e 18 a seguir, é possível verificar o perfil de consumo de energia do refrigerador medido diretamente na sua tomada de alimentação e este mesmo consumo extraído da curva de carga de toda a instalação através do algoritmo de NILM proposto.

Cabe observar que o resultado obtido pelo algoritmo é muito semelhante à curva medida, exceto por trechos de funcionamento diferenciado do equipamento e por eventuais faltas de medições. 


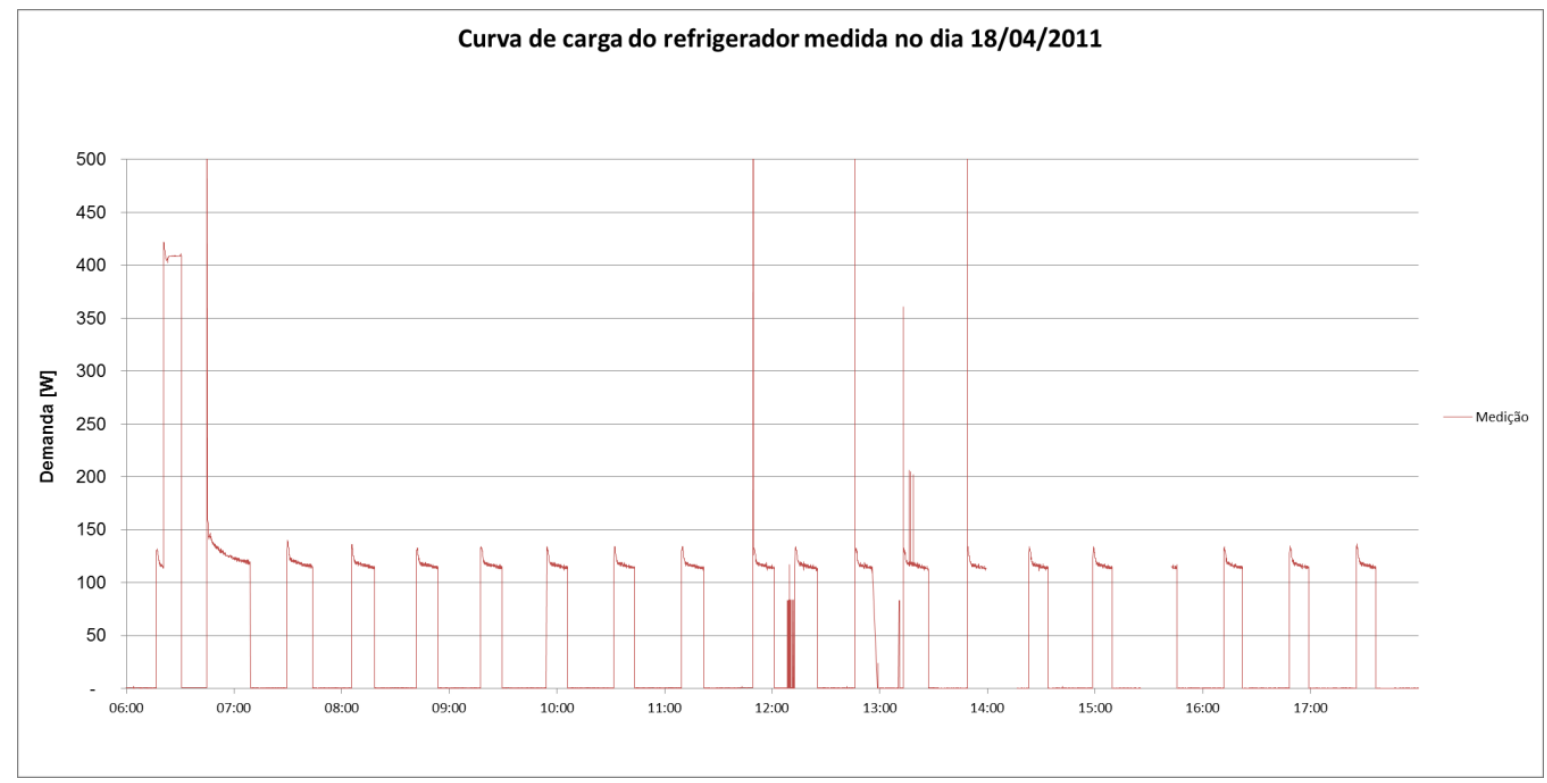

Figura 17 - Curva de carga do refrigerador medida na tomada de alimentação do equipamento.

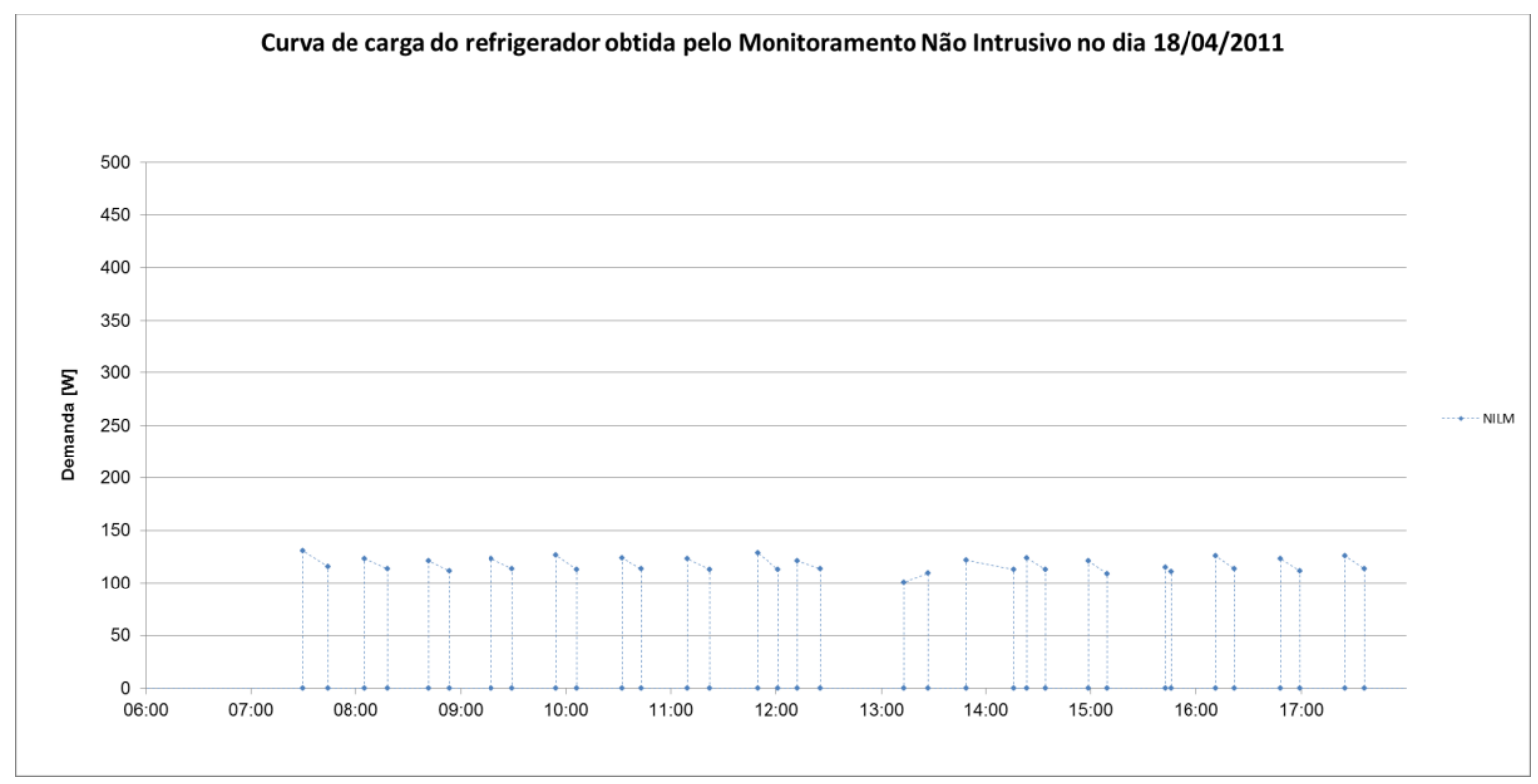

Figura 18 - Curva de carga do refrigerador obtida através do algoritmo proposto.

Um refrigerador possui um funcionamento regular na maior parte do dia, onde o compressor é acionado e permanece ligado até o interior da geladeira atingir a temperatura desejada. No entanto, outras funções podem ser acionadas ao longo do dia, seja para gelar mais um determinado compartimento do equipamento, seja 
para eliminar a formação de gelo em suas paredes. Mesmo ao abrir a porta da geladeira, o ciclo do compressor pode ser alterado interrompendo seu funcionamento precocemente, ou sendo acionado mais rapidamente.

Como as medições individuais dos equipamentos foram realizadas com intervalo de três segundos entre cada registro, muitos dos picos de demanda observados na curva de carga geral, onde a resolução foi de um segundo entre cada medição, não puderam ser visualizados, ressaltando a importância da taxa de amostragem das medições dependendo do tipo de informação que se deseja extrair da curva de carga.

Apresentando bons resultados para esta instalação residencial, serão realizados testes em instalações comerciais, onde a obtenção do consumo desagregado possibilita maiores potenciais de economia quando comparado às instalações comerciais.

\subsection{COMBED}

$\mathrm{Na}$ utilização do NILM no setor comercial, algumas particularidades deste tipo instalação podem ser mais bem aproveitadas pelo algoritmo como a programação horária das atividades, horário de entrada e saída de funcionários, escalas aos finais de semana. Tais características muitas vezes se repetem em outras instalações comerciais, fato que não ocorre frequentemente nas residências, apesar de cada família possuir hábitos que podem se repetir ao longo das semanas, não se pode dizer o mesmo em relação a outras casas, motivo pelo qual essa característica não é muito aproveitável em larga escala nos algoritmos residenciais (Batra et al., 2014).

São comuns nas instalações comerciais as análises dos dias úteis serem realizadas à parte dos finais de semana e feriados. Essa segmentação se dá pelo perfil de ocupação dos usuários, assim como na operação característica dos equipamentos nesses períodos. Ao longo do dia, a segmentação entre horário comercial e o noturno também pode facilitar as análises pelos algoritmos. 
Visando identificar os eventos, e suas respectivas assinaturas, na curva de carga foram analisados os dados do COMBED, tal qual foi realizado para os dados do REDD. Entretanto, conforme ilustrado na figura 19 a seguir, verifica-se que as variações existentes na curva de carga geral da IIITD não possuem padrão em magnitude, duração ou frequência, o que impossibilitou a identificação de muitos eventos ao longo do dia. Verifica-se que a ausência de padrão nas variações se repete no domingo, como ilustrado pela figura 20, no entanto, é possível observar a diferença no perfil de consumo de um dia útil e um final de semana, assim como a semelhança que existe entre os períodos noturnos, após as 20:00h, devido à ausência de usuários na instalação, assim como no início da madrugada, até as 3:00h, também pela ausência de usuários.

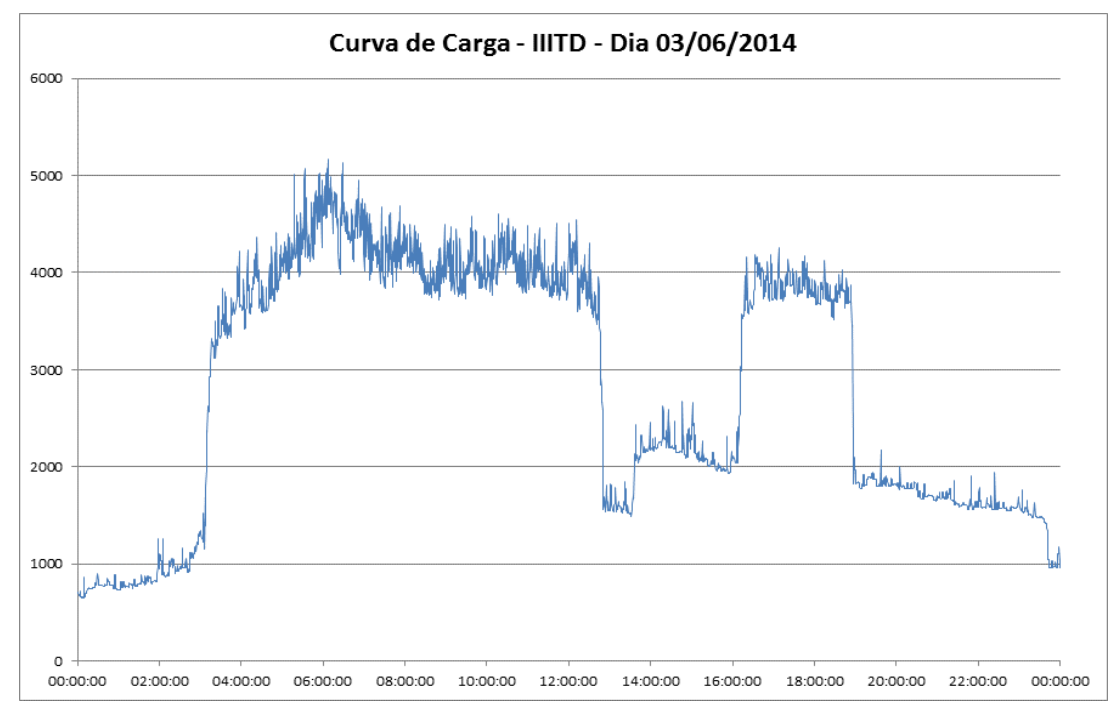

Figura 19 - Curva de Carga do IIITD em uma terça-feira 


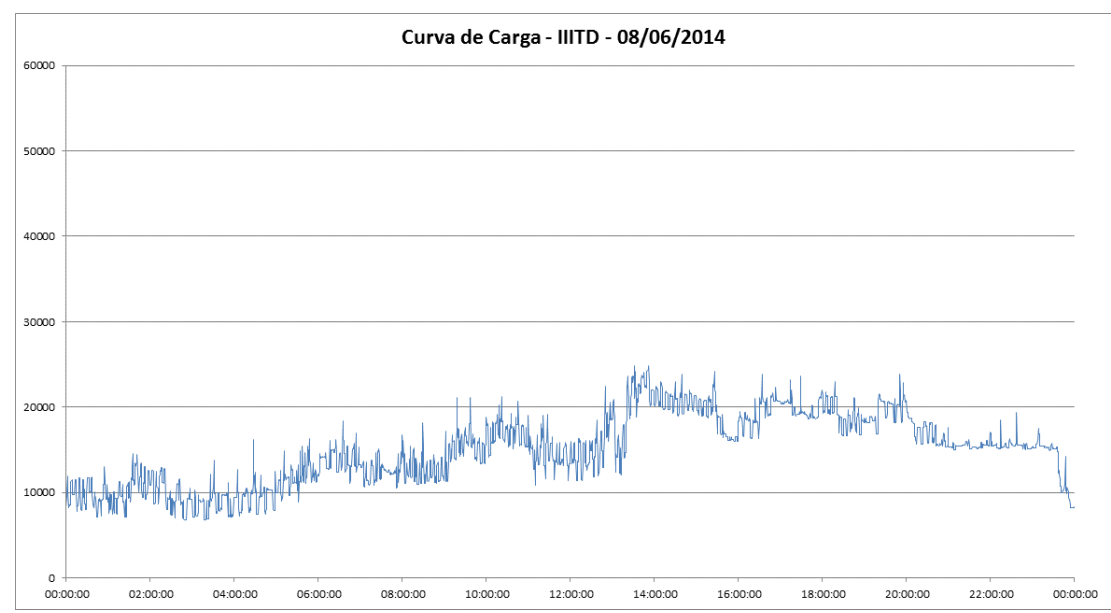

Figura 20 - Curva de carga do IIITD em um domingo

Continuando as análises com os dados do COMBED, aproveitando a disponibilidade de suas medições parciais, a metodologia desenvolvida será avaliada quanto à sua utilização em setores menores. Nota-se, pelo gráfico $21 \mathrm{a}$ seguir, que as oscilações irregulares diminuíram, tornando possível avaliação, ainda que, parcial da carga, onde é possível verificar alguns patamares de possíveis cargas mais bem "comportadas".

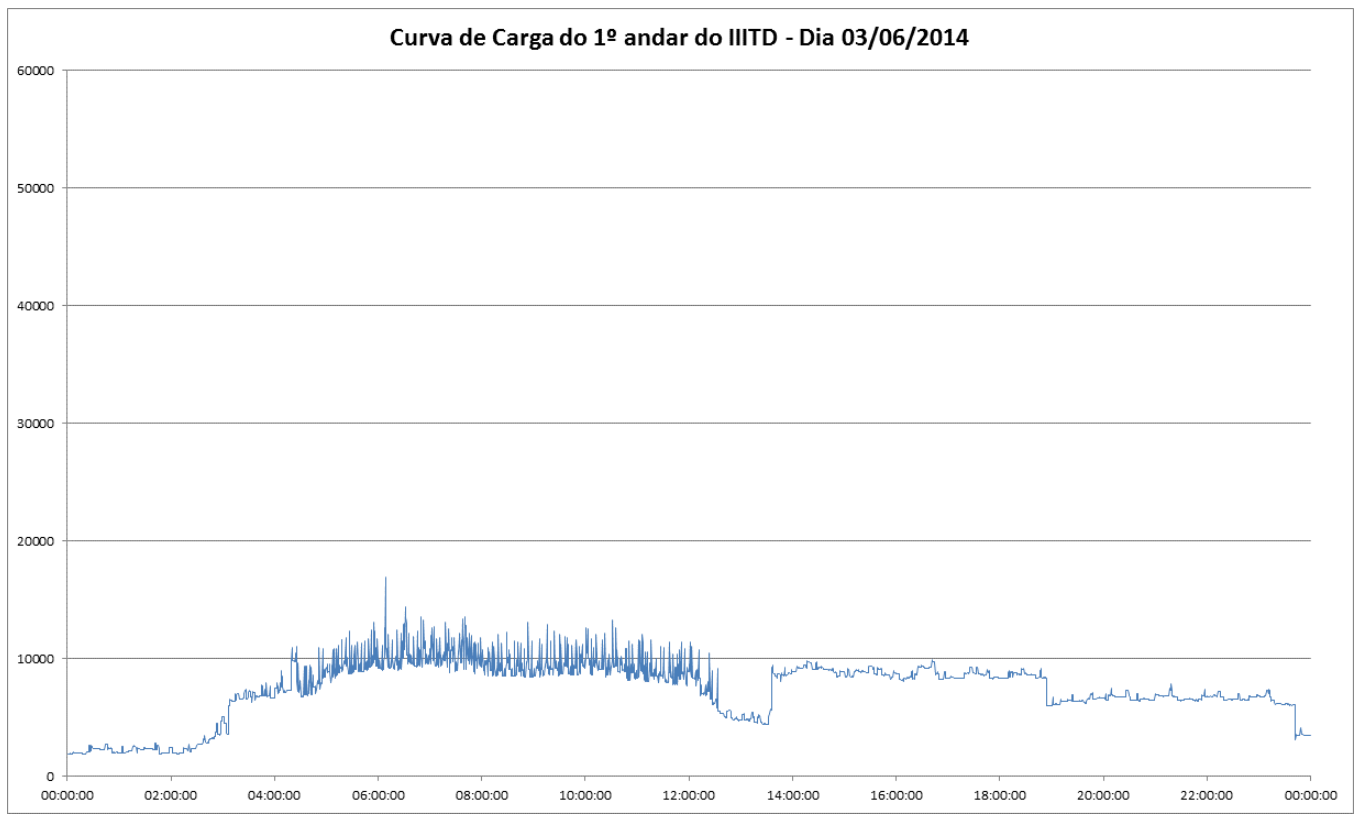

Figura 21 - Curva de carga do $1^{\circ}$ andar do IIITD 
Uma vez que a demanda de energia em uma instalação comercial é muito maior em relação às residenciais, a demanda relativa de energia de cada equipamento em relação ao total da instalação é muito menor. Tal fato influenciou no desempenho do algoritmo de detecção do consumo desagregado, pois as variações de demanda de cada equipamento não puderam ser reconhecidas como evento, mas sim como ruídos que ocorriam frequentemente na curva de carga da instalação.

Outro fator que prejudicou o desempenho do algoritmo proposto foi a resolução dos dados obtidos para a instalação comercial, com uma medição a cada 30 segundos. Tal intervalo entre os registros de demanda, combinado com a maior quantidade de equipamentos presentes nas instalações comerciais, permitem que frequentemente ocorram eventos causados por mais de um equipamento, dificultando a identificação individual de cada um.

Quando disponível, a programação das atividades desenvolvidas associadas a uma relação dos respectivos equipamentos utilizados pode ser mais um subsídio para identificação do consumo desagregado na curva de carga. Tais informações restringem as possibilidades de equipamentos que podem ser os causadores dos eventos, o que pode melhorar o desempenho dos algoritmos de detecção do consumo desagregado. As medições parciais por setores de uma instalação comercial também restringem os equipamentos que podem estar presentes em tal medição, além de aumentar a demanda relativa dos equipamentos em relação à demanda total da medição.

Os aprimoramentos citados anteriormente poderão ser implementados em pesquisas futuras visando aperfeiçoar as técnicas de monitoramento não intrusivo de cargas, permitindo uma gestão mais efetiva do consumo de energia elétrica. 


\section{CONCLUSÕES}

Os Sistemas de Gestão de Energia são importantes ferramentas utilizadas para melhorarem a forma que a energia elétrica é utilizada em uma instalação. Seu diagnóstico energético é baseado nas informações disponibilizadas pelos usuários e gestores da instalação. Quanto mais detalhados forem os dados fornecidos, mais preciso será o diagnóstico.

Informações acerca do consumo desagregado de energia são muito úteis, pois permitem avaliar, com maior assertividade, a eficiência energética dos sistemas utilizados. Assim, o desenvolvimento dos algoritmos de detecção do consumo desagregado, através das técnicas de Monitoramento Não Intrusivo de Carga (NILM), se mostra muito importante, pois permite minimizar a quantidade de medidores necessários para descrição completa dos usos finais de energia na instalação.

Existem casos onde é necessário um único medidor, para detectar todos os eventos em uma instalação, e associá-los aos equipamentos que foram utilizados, constatando a importância da continuidade de desenvolvimento do NILM.

O algoritmo desenvolvido se mostrou muito eficiente na identificação dos eventos que ocorrem em uma instalação residencial. Entretanto, ao ser aplicado em uma instalação comercial, onde a quantidade de equipamentos é maior, assim como a complexidade em seus perfis de funcionamento, encontrou dificuldade para isolar tais eventos, realizando-os de maneira incorreta.

Verificou-se que as recorrentes e irregulares variações de demanda de energia presentes na curva de carga dos grandes consumidores impossibilita a detecção de eventos, considerados regulares, que ocorrem na instalação. Tais irregularidades impedem que as peculiaridades do perfil de consumo de energia dos demais equipamentos sejam identificadas e consequentemente seus valores de consumo desagregado. As medições setorizadas, quando realizadas a jusante do equipamento causador de tais distúrbios, além de eliminar os ruídos, também reduz a quantidade de equipamentos a serem identificados por aquela medição, facilitando o processo de discriminação do consumo. Nota-se, portanto, que 
independente da presença de um dispositivo ruidoso na instalação, a medição setorizada da instalação possibilita um melhor desempenho dos algoritmos de identificação do consumo desagregado, e consequentemente do sistema de gestão de energia.

Desta maneira, destaca-se a importância e a utilidade do Monitoramento Não Intrusivo de Carga para os Sistemas de Gestão de Energia, provendo diagnósticos energéticos mais precisos, o que contribui para o Desenvolvimento Sustentável de toda sociedade.

O aumento do número de pesquisas sobre o NILM permitirá que um vasto banco de dados seja formado para servir de referência para as pesquisas futuras para que, assim como na Biologia Computacional e na Visão por Computador, o reconhecimento de padrões propicie grandes avanços na identificação do consumo desagregado de energia. 


\section{REFERÊNCIAS BIBLIOGRÁFICAS}

ALVAREZ, A. L. M. Uso racional e eficiente de energia elétrica: metodologia para a determinação dos potenciais de conservação dos usos finais em instalações de ensino e similares. Dissertação (Mestrado) - Escola Politécnica, Universidade de São Paulo. São Paulo, 1998.

ANDERSON, K.; OCNEANU, A. F.; BENÍTEZ, D.; CARLSON, D.; ROWE, A. BERGÉS, M. BLUED: A fully labeled public dataset for event-based nointrusive load monitoring research. ACM SustKDD, Beijing, China, 2012.

ANEEL. Procedimentos de distribuição de energia elétrica no sistema elétrico nacional - PRODIST - Módulo 5 - Sistemas de medição. 2011.

ARMEL, K. C.; GUPTA A.; SHRIMALI G.; ALBERT A. Is disaggregation the holy grail of energy efficiency? The case of electricity. Energy Police, v. 52, 2013. pp. $213-234$

ASSOCIAÇÃO BRASILEIRA DE NORMAS TÉCNICAS. ABNT NBR ISO 50001: Sistemas de gestão da energia - Requisitos com orientações de uso. Rio de Janeiro, 2011.

ASSOCIAÇÃO BRASILEIRA DE NORMAS TÉCNICAS. NBR 8995: Iluminação de ambientes de trabalho. Parte 1: Interior. Rio de Janeiro, 2013.

AZZINI, H. A. D.; TORQUATO, R.; SILVA, L. C. P. Event detection methods for nonintrusive load monitoring. PES General Meeting | Conference \& Exposition, 2014 IEEE.

BATRA, N.; PARSON, O.; BERGES, M.; SINGH, A.; ROGERS, A. A comparison of non-intrusive load monitoring methods for commercial and residential buildings. arXiv:1408.6595v1 [cs.SY] 27 Aug 2014

BENAVIDES, J. R. R. A auditoria energética como ferramenta para o aproveitamento do potencial de conservação da energia: o caso das edificações do setor educacional. Dissertação (Mestrado) - Instituto de Energia e Ambiente, Universidade de São Paulo. São Paulo, 2014. 
BRASIL. Lei $n .-10.295$, de 17 de outubro de 2001. Dispõe sobre a Política Nacional de Conservação e Uso Racional de Energia e dá outras providências. Diário Oficial da União, Brasília, DF, 18 out. 2001.

COUGHLIN, K.; PIETTE, M. A.; GOLDMAN, C.; KILICCOTE, S. Statistical analysis of baseline load models for non-residential building. Environmental Energy Technologies Division. Energy and Buildings, v. 41, issue 4, pp. 374-381.

BRASIL. Lei $n .-12.212,20$ de janeiro de 2010. Dispõe sobre a Tarifa Social de Energia Elétrica; altera as Leis nos 9.991, de 24 de julho de 2000, 10.925, de 23 de julho de 2004, e 10.438, de 26 de abril de 2002; e dá outras providências. Diário Oficial da União, Brasília, DF, 21 jan. 2010.

ELETROBRAS; PROCEL. Relatório de resultados do Procel 2013 - ano base 2012. Rio de Janeiro, 2013.

ELETROBRÁS / PROCEL EDUCAÇÃO. Eficiência energética - teoria \& prática. Universidade Federal de Itajubá, Itajuba, 2007.

EVO. Protocolo Internacional de Medição e Verificação de Performance. Efficiency Valuation Organization. EVO10000 - 1:2012 (Br)

FAVATO, L. B. Indicadores de eficiência energética em edifícios da USP: concepção, aplicabilidade e desdobramentos energético-ambientais associados. Dissertação (Mestrado) - Instituto de Pesquisas Tecnológicas do Estado de São Paulo. São Paulo, 2005.

FAVATO, L. B; PINTO, R. T. S. Análises de metodologias de gestão de energia e proposições visando suas implementações: Universidade de São Paulo Estudo de caso. Monografia (MBA em Energia) - Escola Politécnica, Universidade de São Paulo. São Paulo, 2009

HART, G. W. Prototype Nonintrusive Appliance Load Monitor. MIT Energy Laboratory. Massachusetts, 1985.

KANASHIRO, E.; MAKIYAMA, R. Análise de Indicadores de Energia Elétrica. Projeto de Formatura - Escola Politécnica, Universidade de São Paulo. São Paulo, 2011. 
KOLTER, J. Z.; JOHNSON, M. J. REDD: A public data set for energy disaggregation research. In proceedings of the SustKDD workshop on Data Mining Applications in Sustainability, 2011.

LAMMERS, N.; SEVER, F.; ABELS, B.; KISSOC, K. Measuring progress with normalized energy intensity. Department of Mechanical and Aerospace Enginnering, University of Dayton, Dayton, Ohio, 2011.

LEITE, F. C. Modelamento da eficiência energética para o gerenciamento sustentavel no setor industrial pela medição e verificação. Dissertação (Mestrado) - Escola Politécnica, Universidade de São Paulo. São Paulo, 2010.

MORALES, C. Indicadores de consumo de energia elétrica como ferramentas de apoio à gestão: classificação por prioridades de atuação na Universidade de São Paulo. Dissertação (Mestrado) - Escola Politécnica, Universidade de São Paulo. São Paulo, 2007.

PARSON, O. Unsupervised Training methods for non-intrusive appliance load monitoring from smart meter data. Thesis (Doctor of Philosofy) - Faculty of Physical Science and Engineering, University of Southampton, Hampshire, 2014.

PARSON, O.; GHOSH, S., WEAL, M., ROGERS, A. Non-intrusive Load Monitoring using prior models of general appliance types. University of Southampton, Hampshire, 2012.

PRICE, P. N. Methods for analyzing electric load shape and its variability. California Energy Commission. Lawrence Berkeley National Laboratory. Publication number: CEC-XXX-2010-XXX

ROSA, L. H. L. Sistema de apoio à gestão de utilidades e energia: aplicação de conceitos de sistemas de informação e de apoio à tomada de decisão. Dissertação (Mestrado) - Escola Politécnica, Universidade de São Paulo. São Paulo, 2007.

SAIDEL, M. A. A gestão de energia elétrica na USP: o programa permanente para o uso eficiente de energia elétrica. Tese (Livre Docência) - Escola Politécnica, Universidade de São Paulo. São Paulo, 2005. 
SAIDEL, M. A; GIMENES, A. L. V.; MORALES, C.; LADEIRA, R. Ferramenta computacional para previsão de curva de carga a partir da previsão de temperatura ambiente. In: Internacional Congress on Electricity Distriduition. CIDEL. Buenos Aires. Argentina, 2006.

ZEIFMAN, M.; ROTH, K. Nonintrusive Appliance Load Monitoring: Review and Outlook. IEEE Transactions on Consumer Electronics, Vol. 57, No. 1, February 2011. 